Cover: View of Lookout Creek near Blue River, Oregon. (Photograph ${ }^{\odot}$ by Denny Wentz, October 2004. Used with permission.) 


\section{Environmental Settings of Selected Streams Sampled for Mercury in Oregon, Wisconsin, and Florida, 2002-06}

By Amanda H. Bell and Michelle A. Lutz

National Water-Quality Assessment Program

Open-File Report 2008-1277 


\section{U.S. Department of the Interior DIRK KEMPTHORNE, Secretary}

\section{U.S. Geological Survey \\ Mark D. Myers, Director}

\section{U.S. Geological Survey, Reston, Virginia: 2008}

For product and ordering information:

World Wide Web: http://www.usgs.gov/pubprod

Telephone: 1-888-ASK-USGS

For more information on the USGS--the Federal source for science about the Earth, its natural and living resources, natural hazards, and the environment:

World Wide Web: http://www.usgs.gov

Telephone: 1-888-ASK-USGS

Any use of trade, product, or firm names is for descriptive purposes only and does not imply endorsement by the U.S. Government.

Although this report is in the public domain, permission must be secured from the individual copyright owners to reproduce any copyrighted materials contained within this report.

Suggested citation:

Bell, A.H., and Lutz, M.A., 2008, Environmental settings of selected streams sampled for mercury in Oregon, Wisconsin, and Florida, 2002-06: U.S. Geological Survey Open-File Report 2008-1277, 34 p. 


\section{Foreword}

The U.S. Geological Survey (USGS) is committed to providing the Nation with credible scientific information that helps to enhance and protect the overall quality of life and that facilitates effective management of water, biological, energy, and mineral resources (http://www.usgs. gov/). Information on the Nation's water resources is critical to ensuring long-term availability of water that is safe for drinking and recreation and is suitable for industry, irrigation, and fish and wildlife. Population growth and increasing demands for water make the availability of that water, now measured in terms of quantity and quality, even more essential to the long-term sustainability of our communities and ecosystems.

The USGS implemented the National Water-Quality Assessment (NAWQA) Program in 1991 to support national, regional, State, and local information needs and decisions related to waterquality management and policy (http://water.usgs.gov/nawqa). The NAWQA Program is designed to answer: What is the condition of our Nation's streams and ground water? How are conditions changing over time? How do natural features and human activities affect the quality of streams and ground water, and where are those effects most pronounced? By combining information on water chemistry, physical characteristics, stream habitat, and aquatic life, the NAWQA Program aims to provide science-based insights for current and emerging water issues and priorities. From 1991-2001, the NAWQA Program completed interdisciplinary assessments and established a baseline understanding of water-quality conditions in 51 of the Nation's river basins and aquifers, referred to as Study Units (http://water.usgs.gov/nawqa/studyu.html).

Multiple national and regional assessments are ongoing in the second decade (2001-2012) of the NAWQA Program as 42 of the 51 Study Units are reassessed. These assessments extend the findings in the Study Units by determining status and trends at sites that have been consistently monitored for more than a decade, and filling critical gaps in characterizing the quality of surface water and ground water. For example, increased emphasis has been placed on assessing the quality of source water and finished water associated with many of the Nation's largest community water systems. In addition, national syntheses of information on pesticides, volatile organic compounds (VOCs), nutrients, selected trace elements, and aquatic ecology are continuing.

The USGS aims to disseminate credible, timely, and relevant science information to address practical and effective water-resource management and strategies that protect and restore water quality. We hope this NAWOA publication will provide you with insights and information to meet your needs, and will foster increased citizen awareness and involvement in the protection and restoration of our Nation's waters.

The USGS recognizes that a national assessment by a single program cannot address all water-resource issues of interest. External coordination at all levels is critical for cost-effective management, regulation, and conservation of our Nation's water resources. The NAWQA Program, therefore, depends on advice and information from other agencies-Federal, State, regional, interstate, Tribal, and local-as well as nongovernmental organizations, industry, academia, and other stakeholder groups. Your assistance and suggestions are greatly appreciated.

Matthew C. Larsen

Associate Director for Water 
This page intentionally left blank. 


\section{Contents}

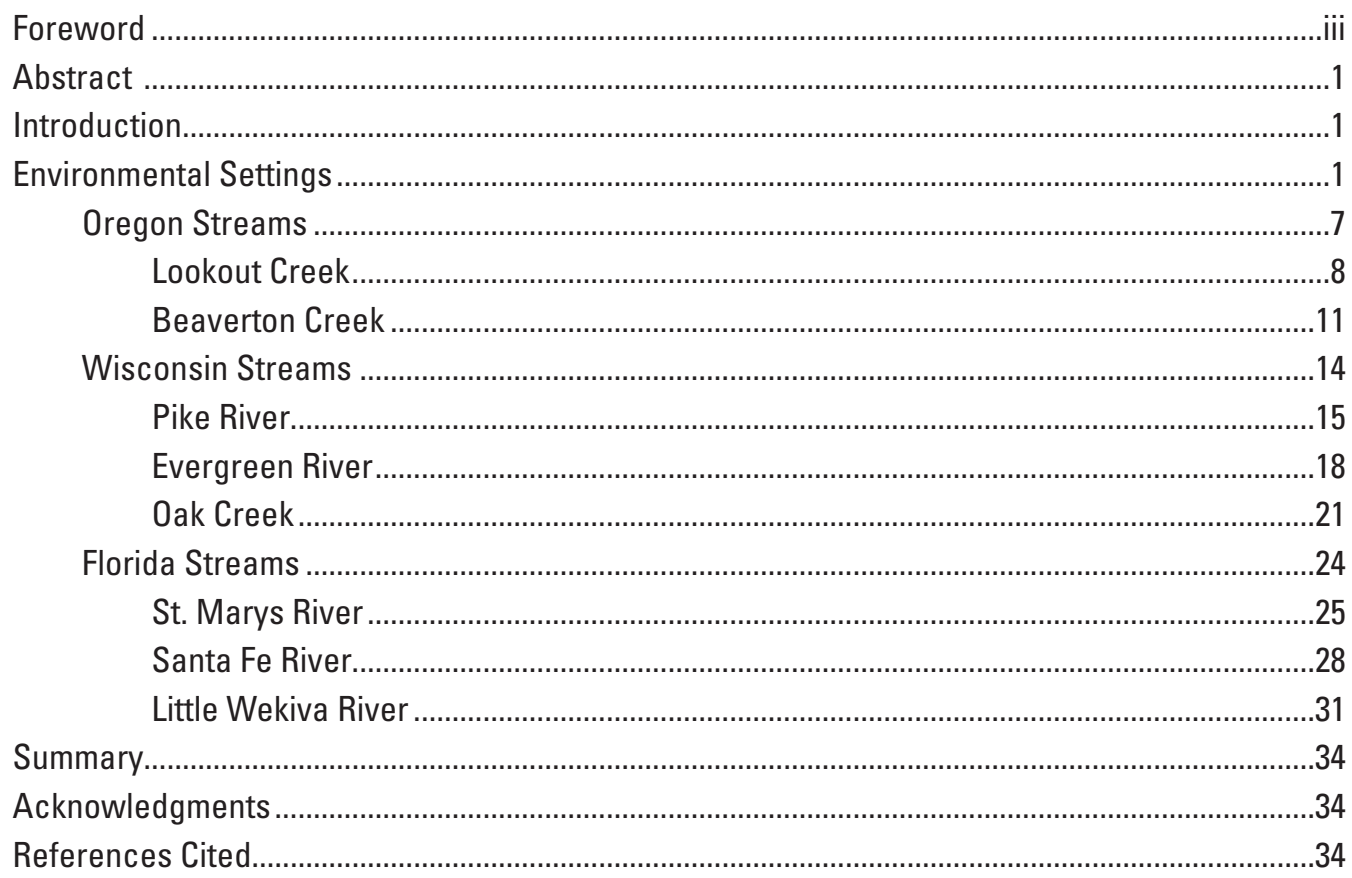

\section{Figures}

Figure 1. Map showing locations of sites sampled for National Water-Quality Assessment (NAWQA) Program mercury studies, 2002-06

Figure 2. Map showing stream basins, U.S. Environmental Protection Agency Level III Ecoregions, and selected sampling sites associated with Oregon streams sampled for National Water-Quality Assessment (NAWQA) Program mercury studies, 2002-06.

Figure 3. Photograph showing Lookout Creek near Blue River, Oreg., (looking upstream) sampled for National Water-Quality Assessment (NAWQA) Program mercury studies, 2002-06

Figure 4. Map showing land cover, location of streamflow gage, and selected sampling sites associated with Lookout Creek near Blue River, Oreg., basin sampled for National Water-Quality Assessment (NAWQA) Program mercury studies, 2002-06

Figure 5. Orthophoto showing location of streamflow, surface-water, streambed-sediment, pore-water, periphyton, invertebrate, and fish sampling at Lookout Creek near Blue River, Oreg., sampled for National Water-Quality Assessment (NAWQA) Program mercury studies, 2002-06

Figure 6. Photograph showing Beaverton Creek at Southwest 216th Avenue, near Orenco, Oreg., (looking upstream) sampled for National Water-Quality Assessment (NAWQA) Program mercury studies, 2002-06 


\section{Figures-Continued}

Figure 7. Map showing land cover, location of streamflow gage, and selected sampling sites associated with Beaverton Creek at Southwest 216th Avenue, near Orenco, Oreg., basin sampled for National Water-Quality Assessment (NAWQA) Program mercury studies, 2002-06

Figure 8. Orthophoto showing ILocation of streamflow, surface-water, streambed-sediment, pore-water, periphyton, invertebrate, and fish sampling at Beaverton Creek at Southwest 216th Avenue, near Orenco, Oreg., sampled for National Water-Quality Assessment (NAWQA) Program mercury studies, 2002-06

Figure 9. Map showing stream basins, U.S. Environmental Protection Agency Level III Ecoregions, and selected sampling sites associated with Wisconsin streams sampled for National Water-Quality Assessment (NAWQA) Program mercury studies, 2002-06.

Figure 10. Photograph showing Pike River at Amberg, Wis., (looking upstream) sampled for National Water-Quality Assessment (NAWQA) Program mercury studies, 2002-06

Figure 11. Map showing land cover, location of streamflow gage, and selected sampling sites associated with Pike River at Amberg, Wis., basin sampled for National Water-Quality Assessment (NAWQA) Program mercury studies, 2002-06

Figure 12. Orthophoto showing location of streamflow, surface-water, streambed-sediment, pore-water, periphyton, invertebrate, and fish sampling at Pike River at Amberg, Wis., sampled for National Water-Quality Assessment (NAWQA) Program mercury studies, 2002-06

Figure 13. Photograph showing Evergreen River below Evergreen Falls near Langlade, Wis., (looking upstream) sampled for National Water-Quality Assessment (NAWQA) Program mercury studies, 2002-06

Figure 14. Map showing land cover, location of streamflow gage, and selected sampling sites associated with Evergreen River below Evergreen Falls near Langlade, Wis., basin sampled for National Water-Quality Assessment (NAWQA) Program mercury studies, 2002-06

Figure 15. Orthophoto showing location of streamflow, surface-water, streambed-sediment, pore-water, periphyton, invertebrate, and fish sampling at Evergreen River below Evergreen Falls near Langlade, Wis., sampled for National Water-Quality Assessment (NAWQA) Program mercury studies, 2002-06

Figure 16. Photograph showing Oak Creek at South Milwaukee, Wis., (looking upstream) sampled for National Water-Quality Assessment (NAWQA) Program mercury studies, 2002-06.

Figure 17. Map showing land cover, location of streamflow gage, and selected sampling sites associated with Oak Creek at South Milwaukee, Wis., basin sampled for National Water-Quality Assessment (NAWQA) Program mercury studies, 2002-06 


\section{Figures-Continued}

Figure 18. Orthophoto showing location of streamflow, surface-water, streambed-sediment, pore-water, periphyton, invertebrate, and fish sampling at Oak Creek at South Milwaukee, Wis., sampled for National Water-Quality Assessment (NAWQA) Program mercury studies, 2002-06

Figure 19. Map showing stream basins, U.S. Environmental Protection Agency Level III Ecoregions, and selected sampling sites associated with Florida streams sampled for National Water-Quality Assessment (NAWQA) Program mercury studies, 2002-06.

Figure 20. Photograph showing St. Marys River near Macclenny, Fla., (looking upstream) sampled for National Water-Quality Assessment (NAWQA) Program mercury studies, 2002-06

Figure 21. Map showing land cover, location of streamflow gage, and selected sampling sites associated with St. Marys River near Macclenny, Fla., basin sampled for National Water-Quality Assessment (NAWQA) Program mercury studies, 2002-06

Figure 22. Orthophoto showing location of streamflow, surface-water, streambed-sediment, pore-water, periphyton, invertebrate, and fish sampling at St. Marys River near Macclenny, Fla., sampled for National Water-Quality Assessment (NAWQA) Program mercury studies, 2002-06

Figure 23. Photograph showing Santa Fe River near Fort White, Fla., (looking downstream) sampled for National Water-Quality Assessment (NAWQA) Program mercury studies, 2002-06

Figure 24. Map showing land cover, location of streamflow gage, and selected sampling sites associated with Santa Fe River near Fort White, Fla., basin sampled for National Water-Quality Assessment (NAWQA) Program mercury studies, 2002-06

Figure 25. Orthophoto showing location of streamflow, surface-water, streambed-sediment, pore-water, periphyton, invertebrate, and fish sampling at Santa Fe River near Fort White, Fla., sampled for National Water-Quality Assessment (NAWQA) Program mercury studies, 2002-06

Figure 26. Photograph showing Little Wekiva River near Longwood, Fla., (looking downstream) sampled for National Water-Quality Assessment (NAWQA) Program mercury studies, 2002-06

Figure 27. Map showing Land cover, location of streamflow gage, and selected sampling sites associated with Little Wekiva River near Longwood, Fla., basin sampled for National Water-Quality Assessment (NAWQA) Program mercury studies, 2002-06.

Figure 28. Orthophoto showing location of streamflow, surface-water, streambed-sediment, pore-water, periphyton, invertebrate, and fish sampling at Little Wekiva River near Longwood, Fla., sampled for National Water-Quality Assessment (NAWQA) Program mercury studies, 2002-06 


\section{Tables}

Table 1. Site characteristics for eight streams sampled for National Water-Quality Assessment (NAWQA) Program mercury studies, 2002-06

Table 2. U.S. Environmental Protection Agency Level III Ecoregions, land-cover data, and percent impervious surface data for drainage basins of eight streams sampled for National Water-Quality Assessment (NAWQA) Program mercury studies, 2002-06.

Table 3. Climatological data for eight streams sampled for National Water-Quality Assessment (NAWQA) Program mercury studies, 2002-06

Table 4. Hydrological data for eight streams sampled for National Water-Quality Assessment (NAWQA) Program mercury studies, 2002-06

\section{Conversion Factors, Datums, and Abbreviations and Acronyms}

Conversion Factors

\begin{tabular}{lll}
\hline Multiply & By & To obtain \\
\hline & Length & \\
\hline centimeter $(\mathrm{cm})$ & 0.3937 & inch (in.) \\
kilometer $(\mathrm{km})$ & 0.6214 & mile (mi) \\
meter $(\mathrm{m})$ & 3.281 & foot (ft) \\
\hline & Area & \\
\hline square kilometer $\left(\mathrm{km}^{2}\right)$ & 0.3861 & square mile $\left(\mathrm{mi}^{2}\right)$ \\
\hline & Flow Rate & acre-foot per day (acre-ft/d) \\
\hline cubic meter per second $\left(\mathrm{m}^{3} / \mathrm{s}\right)$ & 70.07 &
\end{tabular}

Temperature in degrees Celsius $\left({ }^{\circ} \mathrm{C}\right)$ may be converted to degrees Fahrenheit $\left({ }^{\circ} \mathrm{F}\right)$ as follows:

$$
{ }^{\circ} \mathrm{F}=\left(1.8 \times^{\circ} \mathrm{C}\right)+32
$$

Datums

Vertical coordinate information is referenced to the North American Vertical Datum of 1988 (NAVD 88).

Horizontal coordinate information is referenced to the North American Datum of 1983 (NAD 83). 


\section{Conversion Factors, Datums, and Abbreviations and Acronyms-Continued}

Abbreviations and Acronyms

\begin{tabular}{ll}
\hline Abbreviation and Acronym & Definition \\
\hline CY & Calendar year \\
GIS & geographic information system \\
MDN & National Atmospheric Deposition Program Mercury Deposition \\
& Network \\
NAWQA & National Water-Quality Assessment Program \\
NCDC & National Climatic Data Center \\
NLCD & National Land Cover Dataset \\
PRISM & Parameter-elevation Regression on Independent Slopes Model \\
USEPA & U.S. Environmental Protection Agency \\
USGS & U.S. Geological Survey \\
\hline
\end{tabular}


This page intentionally left blank. 


\title{
Environmental Settings of Selected Streams Sampled for Mercury in Oregon, Wisconsin, and Florida, 2002-06
}

\author{
By Amanda H. Bell and Michelle A. Lutz
}

\begin{abstract}
From 2002 through 2006, the U.S. Geological Survey National Water-Quality Assessment Program conducted studies investigating mercury biogeochemistry and foodweb bioaccumulation in eight streams from three distinct geographic areas of the United States. These streams varied greatly in environmental characteristics, including land-cover, hydrologic, climatic, and chemical characteristics. They ranged from a clear-water, high-gradient, low-percentage wetland stream in the Cascade Mountains of Oregon, to an urban stream near Milwaukee, Wisconsin, to a low-gradient, blackwater stream draining the Okefenokee and Pinhook Swamps along the Georgia-Florida border. This report summarizes the environmental settings of these eight streams.
\end{abstract}

\section{Introduction}

The U.S. Geological Survey (USGS) National WaterQuality Assessment (NAWQA) Program studied mercury (Hg) biogeochemistry and food-web bioaccumulation in stream ecosystems from 2002 through 2006 (Brigham and others, 2003). Eight streams with different environmental settings were identified in three geographic areas across the United States-two streams in Oregon and three streams each in Wisconsin and Florida (ig. 1, table 1). These studies assessed $\mathrm{Hg}$ and other key physical, chemical, and biological measures in the eight stream ecosystems. The purpose of this report is to describe the environmental settings of the eight streams and to serve as a reference document for other technical and interpretative reports associated with the 2002-06 Hg studies. Discussions of environmental settings for each of the streams are organized by the States where they are located. Streams are categorized as nonurban, high-percentage wetland; nonurban, low-percentage wetland; or urban, by State.

\section{Environmental Settings}

Data describing environmental settings of streams were compiled from a variety of sources. Stream order for all streams described in this report is based on the Horton and Strahler stream classification system (Horton, 1947; Strahler, 1957). Atmospheric wet deposition Hg concentrations near each of the eight stream sites were determined for selected National Atmospheric Deposition Program Mercury Deposition Network (MDN) sites (site information available at http://nadp.sws.uiuc.edu/mdn/) (table 1). For each drainage basin, U.S. Environmental Protection Agency (USEPA) Level III Ecoregions are identified (U.S. Environmental Protection Agency, 2005), and summaries of land-cover and impervious surface data determined in a geographic information system (GIS) environment, using 2001 National Land Cover Dataset (NLCD) data, are provided (table 2) (Homer and others, 2004; Yang and others, 2002). Air temperature data were summarized from National Climatic Data Center (NCDC) sites located near each stream (National Climatic Data Center, 2007), and stream-water temperature data were summarized from samples collected by field personnel during stream water-quality sample collection (table 3). Precipitation data were summarized for each drainage basin in a GIS environment using the Parameter-elevation Regressions on Independent Slopes Model (PRISM) (Daly and Neilson, 1992; Daly and others, 1994, 1997; Natural Resources Conservation Service, 1998). Streamflow data were collected at USGS streamflow-gaging stations located near each of the eight sampling sites (table 4). In addition to long-term means, annual data for precipitation and streamflow data are provided for calendar years 2002 through 2005, as the majority of in-stream samples were collected during this time frame (tables 3 and 4). Although water years (October of one year through September of the succeeding year) are typically used to summarize annual streamflow data, calendar years are used in this report so that streamflow data could be more readily compared with precipitation and Hg-deposition data, which are traditionally summarized on a calendar year basis. 


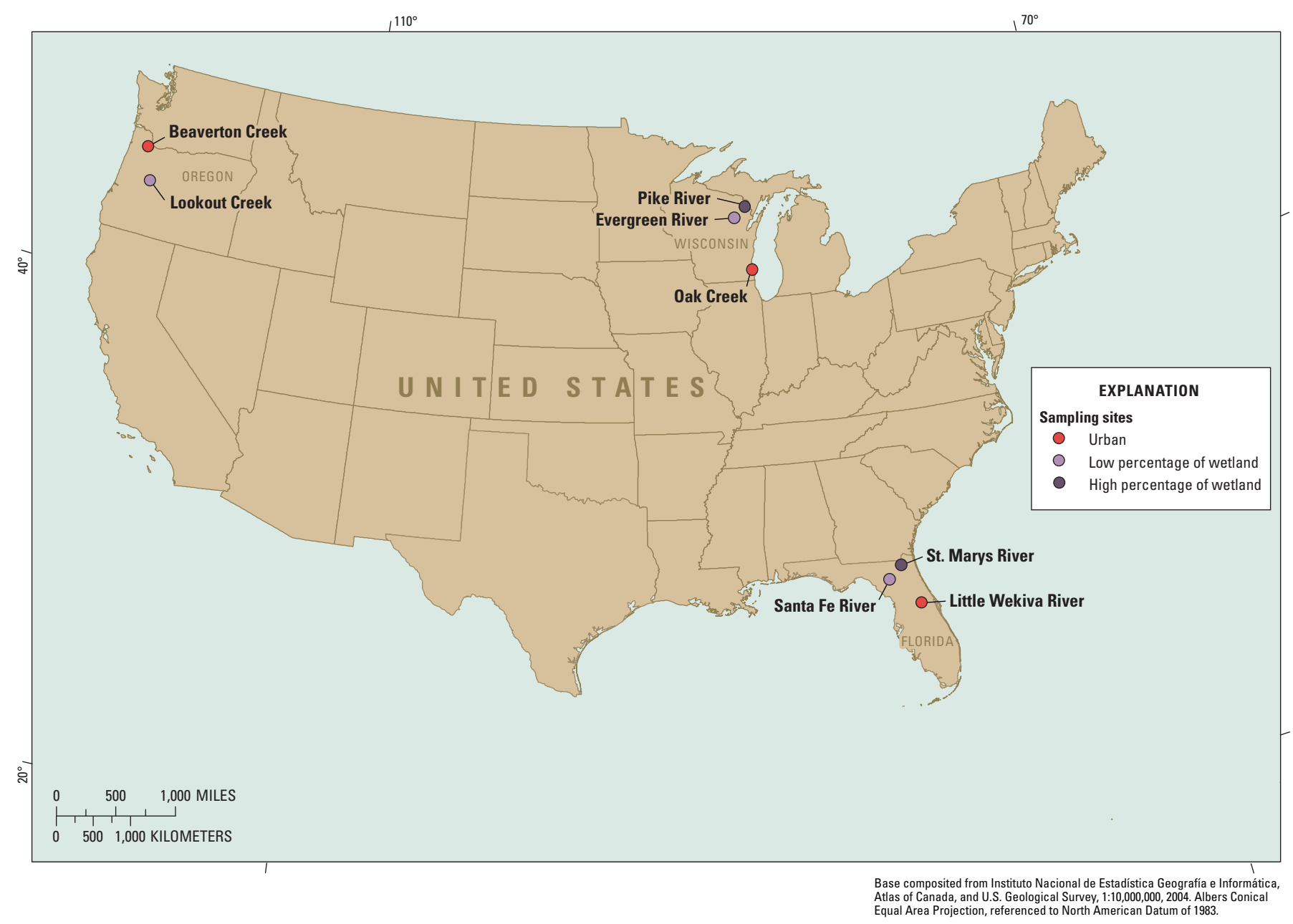

Figure 1. Locations of sites sampled for National Water-Quality Assessment (NAWQA) Program mercury studies, 2002-06.

In this report, figures are provided at a variety of scales to give additional information about the environmental settings of each basin and site. Boundaries of USEPA Level III Ecoregions are shown on maps also displaying stream-basin boundaries, USGS streamflow-gaging stations, stream-water sampling sites, associated MDN sites, and NCDC temperature sampling sites. Photographs showing conditions at or near each stream sampling site were taken by field personnel. Land-cover maps display 2001 NLCD data (Homer and others, 2004), stream-basin boundaries, park and tribal boundaries (where relevant), USGS streamflow-gaging station locations, and stream-water sampling sites, as well as MDN and NCDC temperature sampling sites whenever they were located close enough to the basin to be displayed at the selected scale.

In-stream sampling locations and reaches for various media are shown on digital orthophotos for each stream. Boundaries for various biological reaches are shown on these maps and represent the section of stream where biological samples were collected. Also displayed on these maps are locations sampled for streambed-sediment and pore-water geochemistry and reaches used to characterize streambed sediment (divided into 15 transects, numbered sequentially from downstream to upstream). 


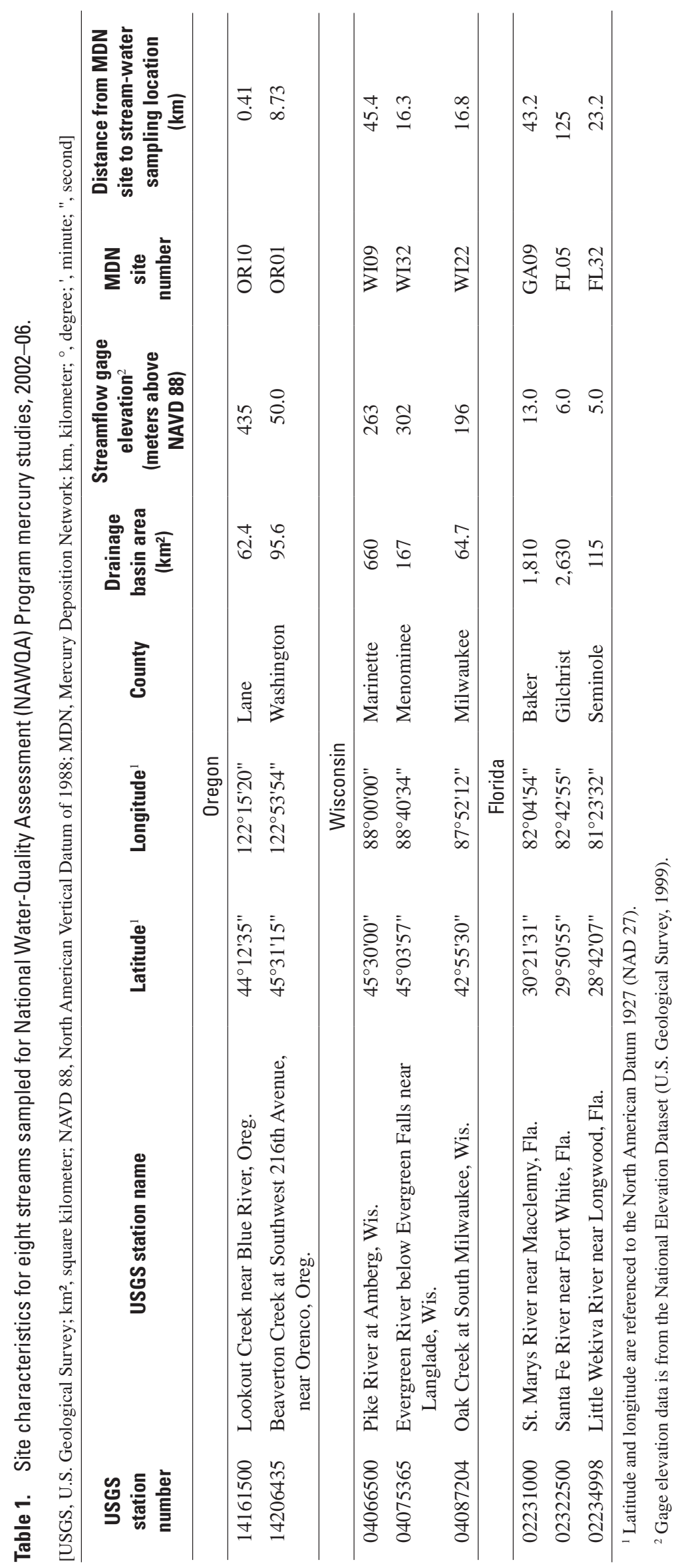




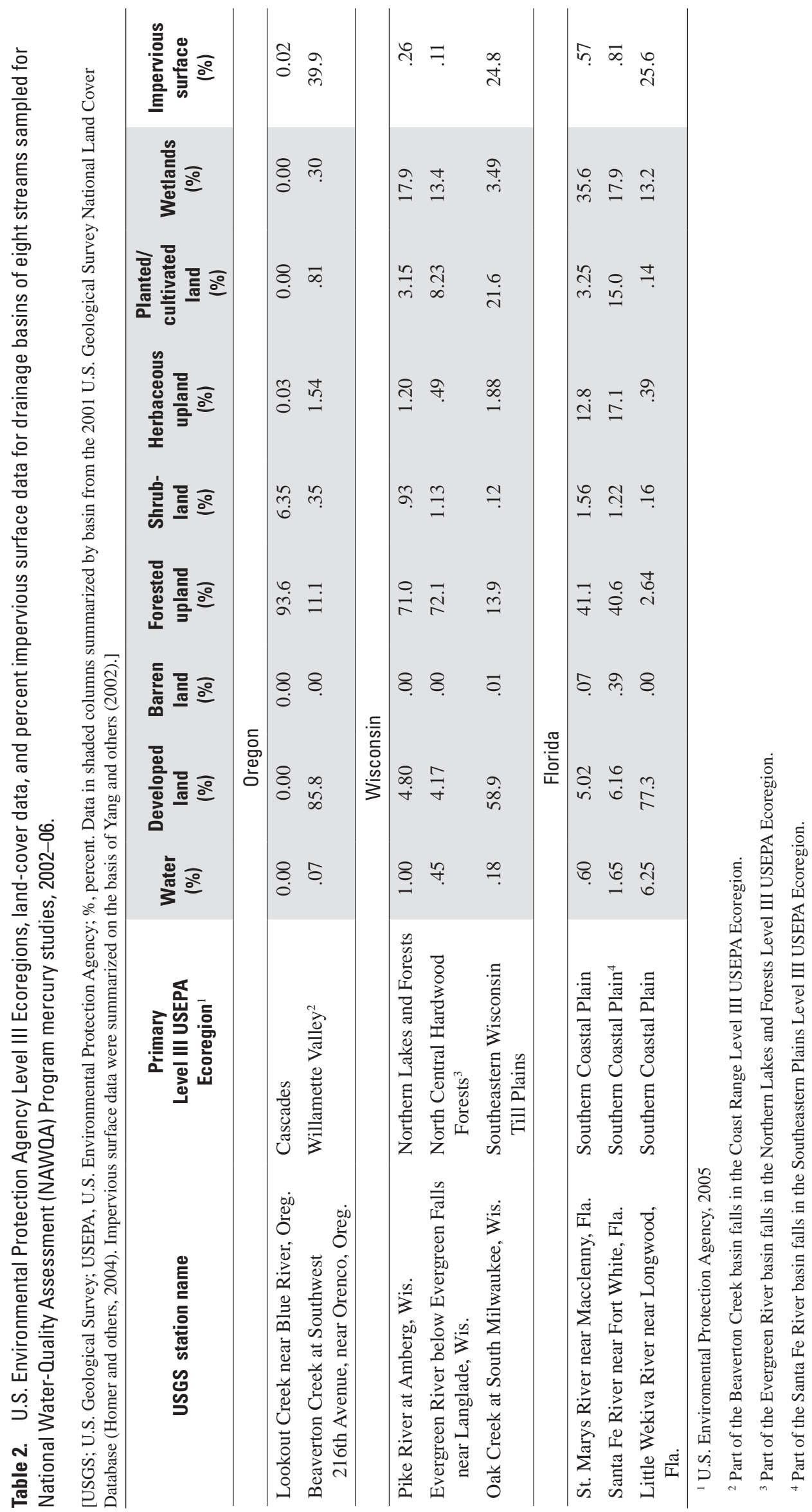




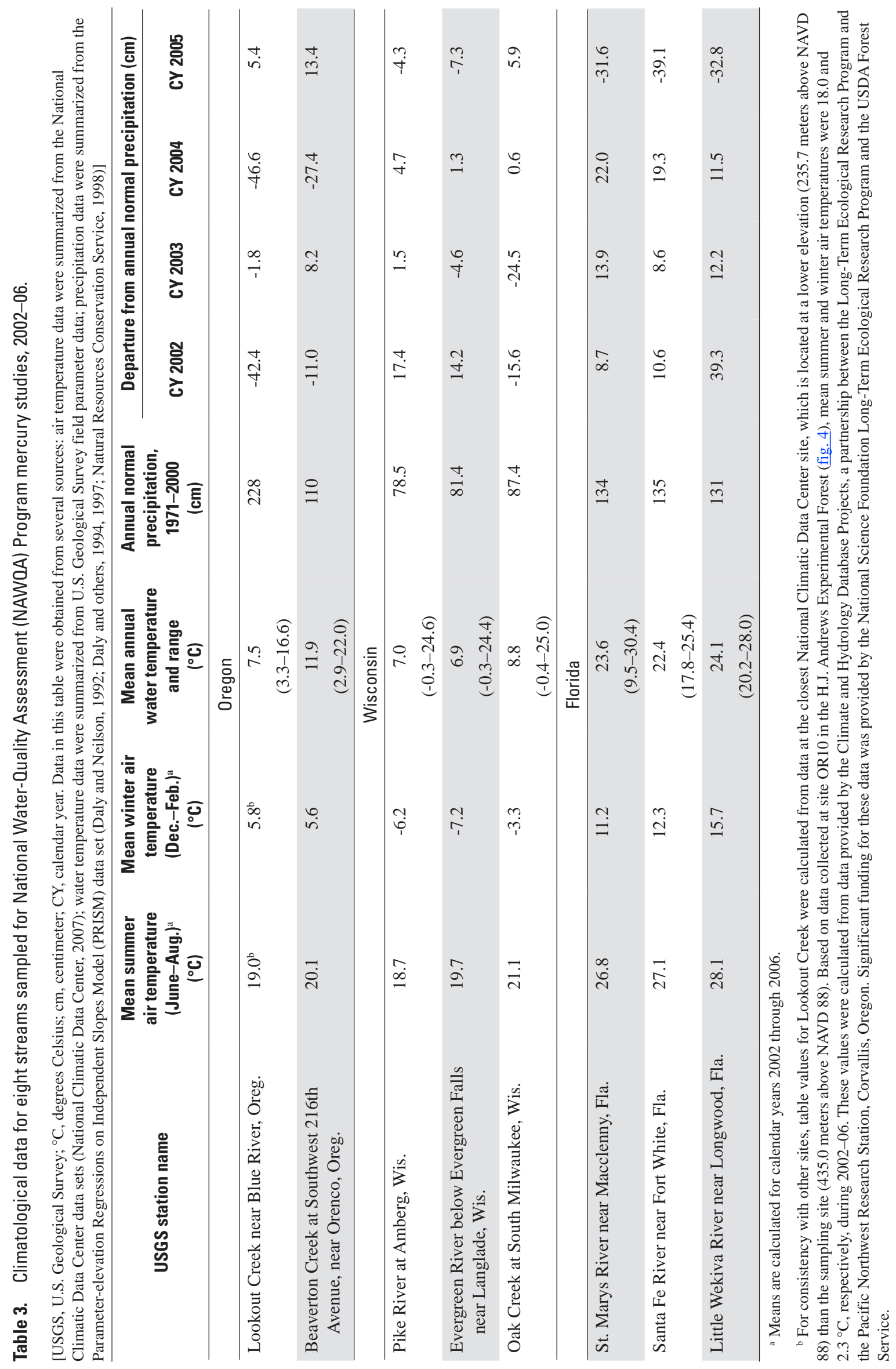




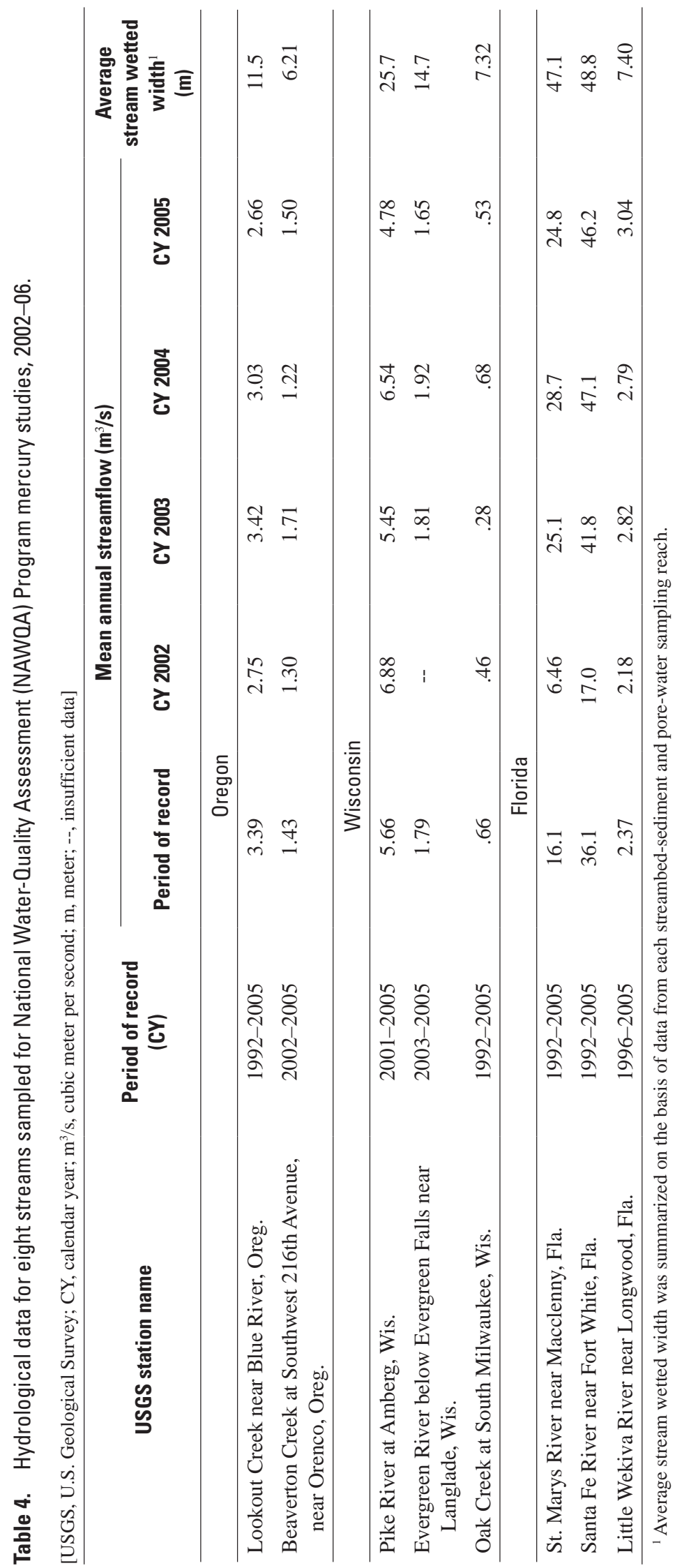




\section{Oregon Streams}

The Oregon sites sampled for the 2002-06 NAWQA Hg studies are Lookout Creek near Blue River, Oreg., and Beaverton Creek at Southwest 216th Avenue, near Orenco, Oreg. (fig. 2, table 1). Lookout Creek is a nonurban, lowpercentage wetland stream located in the Cascade Mountains in west-central Oregon; Beaverton Creek is an urban stream located near Portland, Oregon. Drainage basins of both streams have small percentages ( 0 and 0.30 percent, respectively) of wetland land cover compared to basins of the other six streams studied (table 2).

This area of the country is known for its mild climate. Mean air temperatures near the two Oregon sampling sites ranged from about $20^{\circ} \mathrm{C}$ in the summer to about $6^{\circ} \mathrm{C}$ in the winter; annual normal (1971 through 2000) precipitation for drainage basins ranged from $110 \mathrm{~cm}$ in Beaverton Creek basin to $228 \mathrm{~cm}$ in the higher-altitude Lookout Creek basin (tables 1 and $\underline{3}$ ). The following sections describe the environmental settings of the two Oregon streams in greater detail.

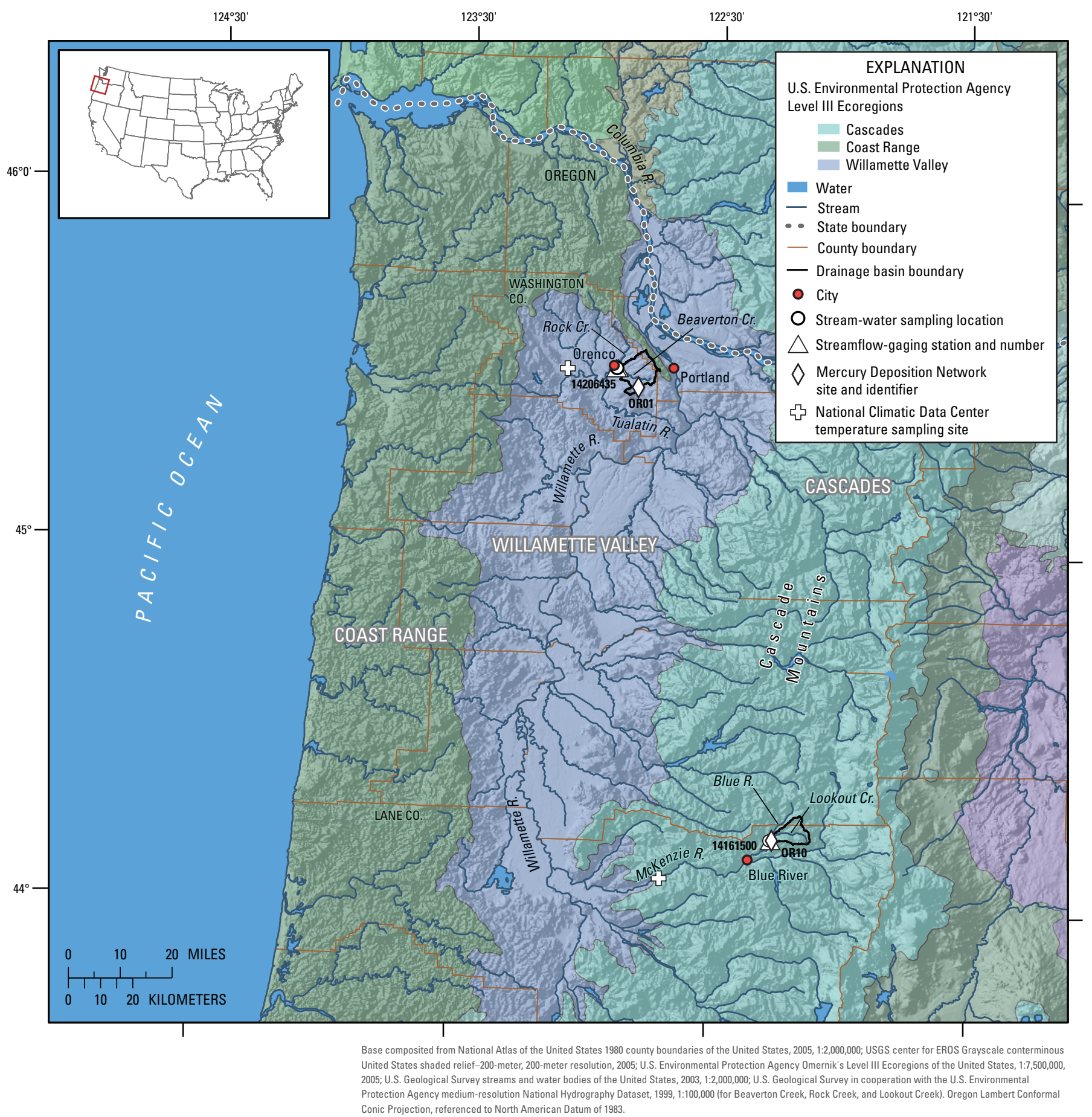

Figure 2. Stream basins, U.S. Environmental Protection Agency Level III Ecoregions, and selected sampling sites associated with Oregon streams sampled for National Water-Quality Assessment (NAWQA) Program mercury studies, 2002-06. 


\section{Lookout Creek}

Lookout Creek is a fourth-order stream, and the sampling site is located in Lane County near Blue River, Oreg. (figs. 2 and $\underline{3}$, table 1). This cold-water trout stream flows through the H.J. Andrews Experimental Forest in the Willamette National Forest (fig. 4). From there, Lookout Creek flows into the Blue River, then into the McKenzie River, into the Willamette River, into the Columbia River, and finally into the Pacific Ocean (fig. 2). The Blue River Dam restricts fish migration from downstream of the reservoir (fig. 4); thus, the fish community in the area sampled includes only indigenous, locally reproducing populations (Oregon Watershed Enhancement Board, 2005).

The Lookout Creek drainage basin covers $62.4 \mathrm{~km}^{2}$ and is located in the Cascades Level III USEPA Ecoregion (fig. 2, tables 1 and 2). Land cover in the basin consists primarily (93.6 percent) of upland forests, and contains no wetlands or developed land (fig. 4, table 2). In-stream sampling locations and reaches are displayed on the digital orthophoto of the stream (fig. 5).

Mean air temperatures from 2002 through 2006 were $19.0^{\circ} \mathrm{C}$ in summer (June through August) and $5.8^{\circ} \mathrm{C}$ in winter (December through February) (table 3). Annual mean water temperatures ranged from $3.3^{\circ} \mathrm{C}$ to $16.6^{\circ} \mathrm{C}$ with a mean of $7.5^{\circ} \mathrm{C}$. Annual normal (1971 through 2000) precipitation for the Lookout Creek drainage basin is $228 \mathrm{~cm}$; precipitation for the 2002 through 2005 calendar years was generally below normal (1.8-46.6 cm), except for 2005 (5.4 cm above normal). Mean annual streamflow for the period of record (calendar years 1992 through 2005) was $3.39 \mathrm{~m}^{3} / \mathrm{s}$ (table 4); from 2002 through 2005 (calendar years) annual streamflow ranged from $2.66 \mathrm{~m}^{3} / \mathrm{s}$ (2005) to $3.42 \mathrm{~m}^{3} / \mathrm{s}$ (2003). The average stream width measured in the bed-sediment and pore-water sampling reach during low-flow conditions was $11.5 \mathrm{~m}$; the streambed substrate was composed primarily of gravel and cobble, with large boulders and outcrops of bedrock.

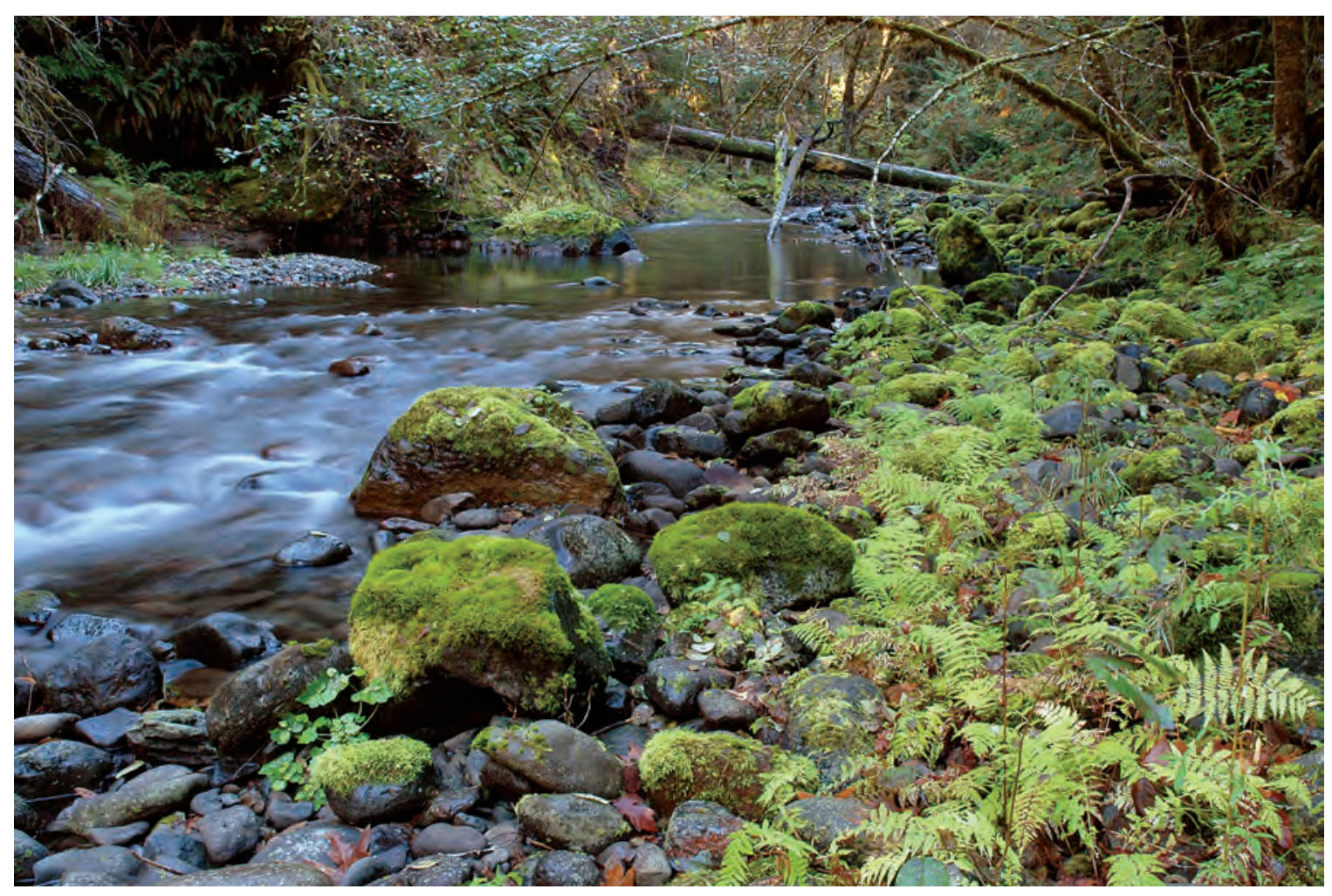

Figure 3. Lookout Creek near Blue River, Oreg., (looking upstream) sampled for National Water-Quality Assessment (NAWQA) Program mercury studies, 2002-06. (Photograph ${ }^{\oplus}$ by Denny Wentz, October 2004. Used with permission.) 


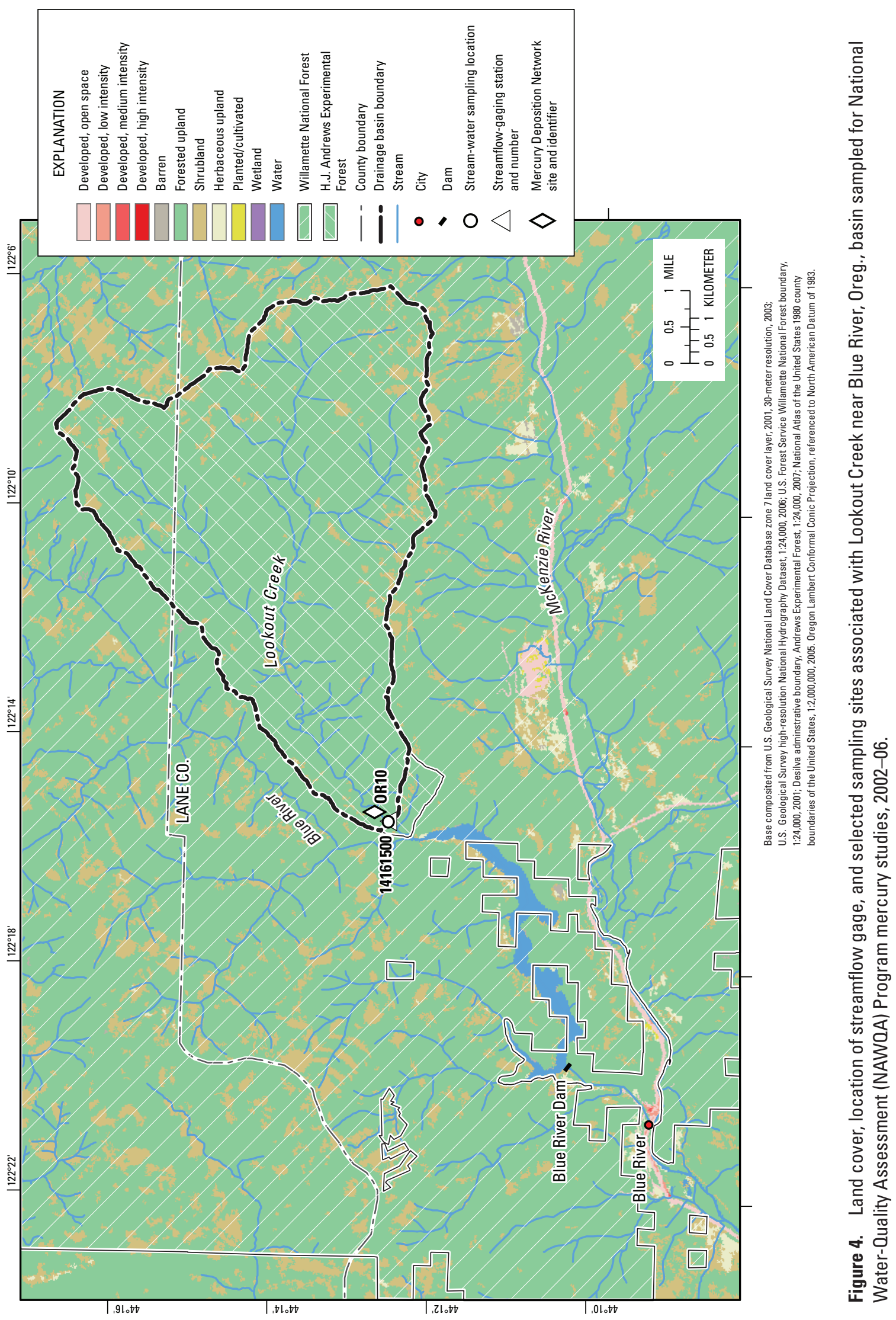




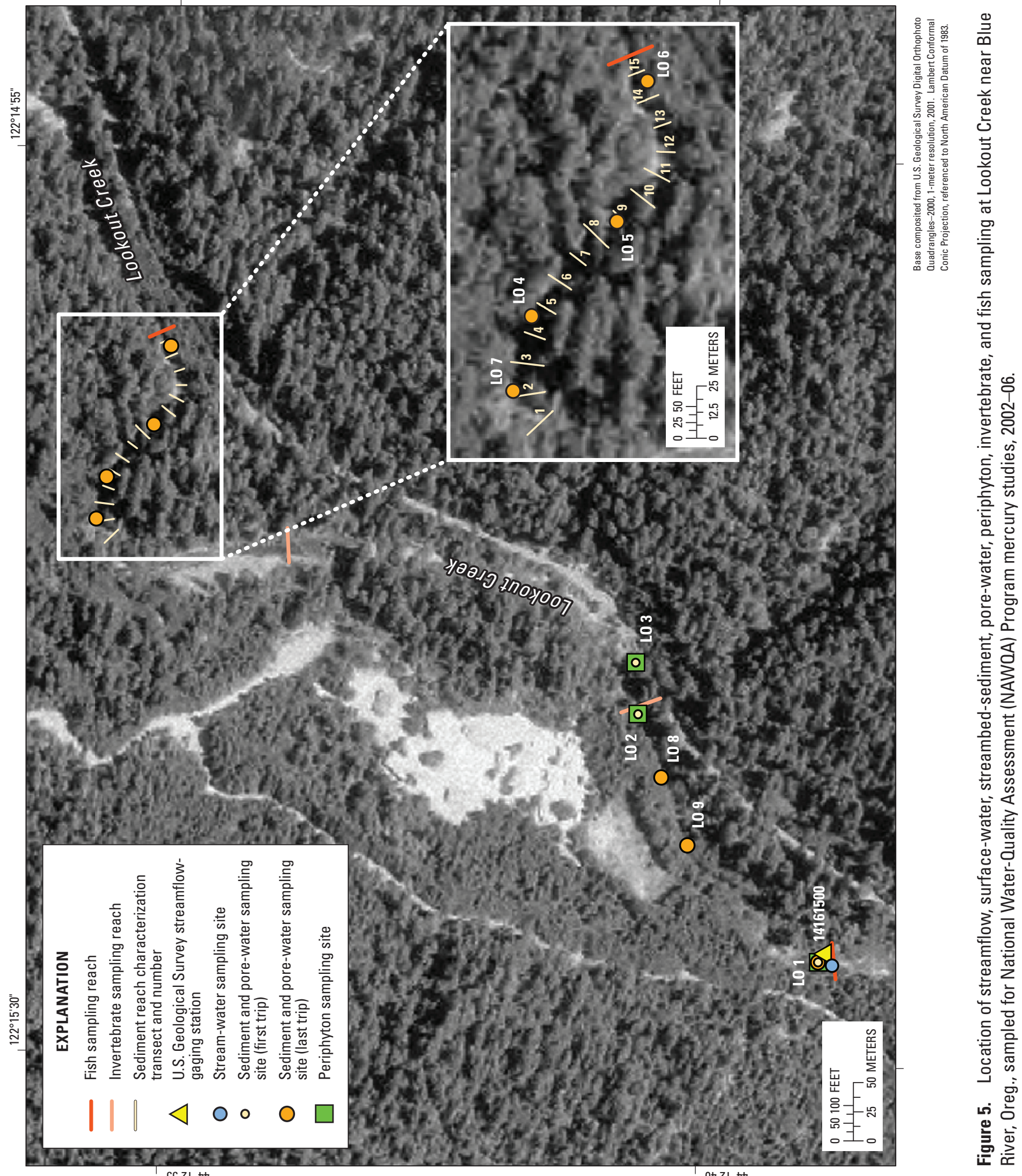




\section{Beaverton Creek}

Beaverton Creek is a fourth-order stream, and the sampling site is located in Washington County near Orenco, Oregon (figs. 2 and $\underline{6}$, table 1 ). This urban stream is located in the Portland metropolitan area (fig. 7). Beaverton Creek flows into Rock Creek, then into the Tualatin River, into the Willamette River, into the Columbia River, and finally into the Pacific Ocean (fig. 2).

The Beaverton Creek drainage basin covers $95.6 \mathrm{~km}^{2}$ (table 1). It is located almost entirely in the Willamette Valley Level III USEPA Ecoregion, with a small part falling in the Coast Range Ecoregion (fig. 2, table 2). Land cover in the basin consists primarily (85.8 percent) of developed land (39.9 percent impervious surface) with less than 1 percent wetland (fig. 7, table 2). The riparian area is composed mainly of deciduous trees, shrubs, residential lawns, and perennial grasses. In-stream sampling locations and reaches are displayed on the digital orthophoto of the stream (fig. 8).

Mean air temperatures from 2002 through 2006 were $20.1^{\circ} \mathrm{C}$ in summer (June through August) and $5.6^{\circ} \mathrm{C}$ in winter (December through February) (table 3). Annual mean water temperatures ranged from $2.9^{\circ} \mathrm{C}$ to $22.0^{\circ} \mathrm{C}$ with a mean of $11.9^{\circ} \mathrm{C}$. Annual normal (1971 through 2000) precipitation for the Beaverton Creek drainage basin is $110 \mathrm{~cm}$; precipitation for the 2002 through 2005 calendar years ranged from $27.4 \mathrm{~cm}$ below (2004) to $13.4 \mathrm{~cm}$ above (2005) normal. Mean annual streamflow for the period of record (calendar years 2002 through 2005) was $1.43 \mathrm{~m}^{3} / \mathrm{s}$ (table 4); during this time annual streamflow ranged from $1.22 \mathrm{~m}^{3} / \mathrm{s}$ (2004) to $1.71 \mathrm{~m}^{3} / \mathrm{s}$ (2003). The average stream width measured in the bed-sediment and pore-water sampling reach during low-flow conditions was $6.21 \mathrm{~m}$; the streambed was composed of gravel, cobble, and fine sediment.

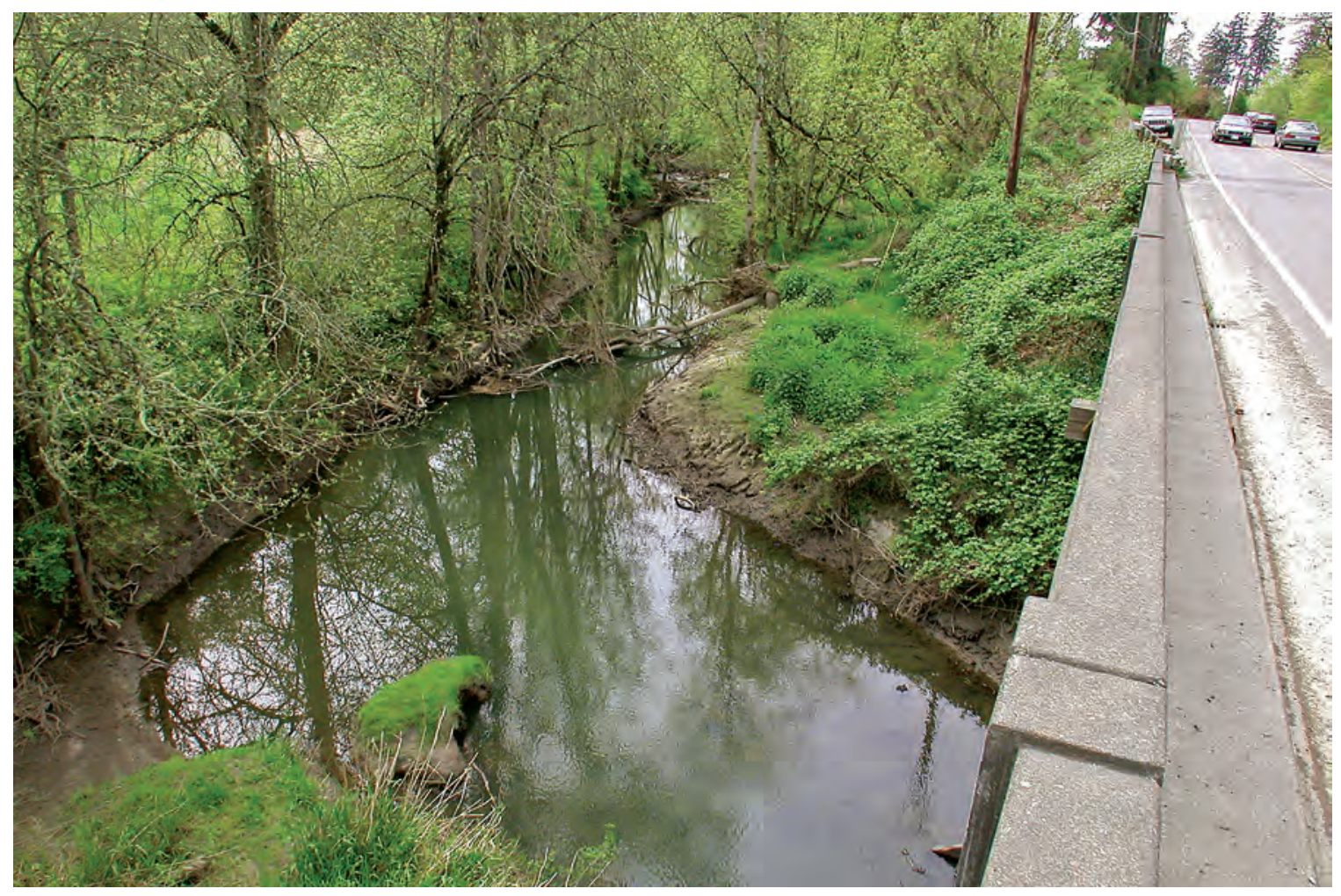

Figure 6. Beaverton Creek at Southwest 216th Avenue, near Orenco, Oreg., (looking upstream) sampled for National Water-Quality Assessment (NAWQA) Program mercury studies, 2002-06. (Photograph by Dennis A. Wentz, U.S. Geological Survey, April 2002.) 


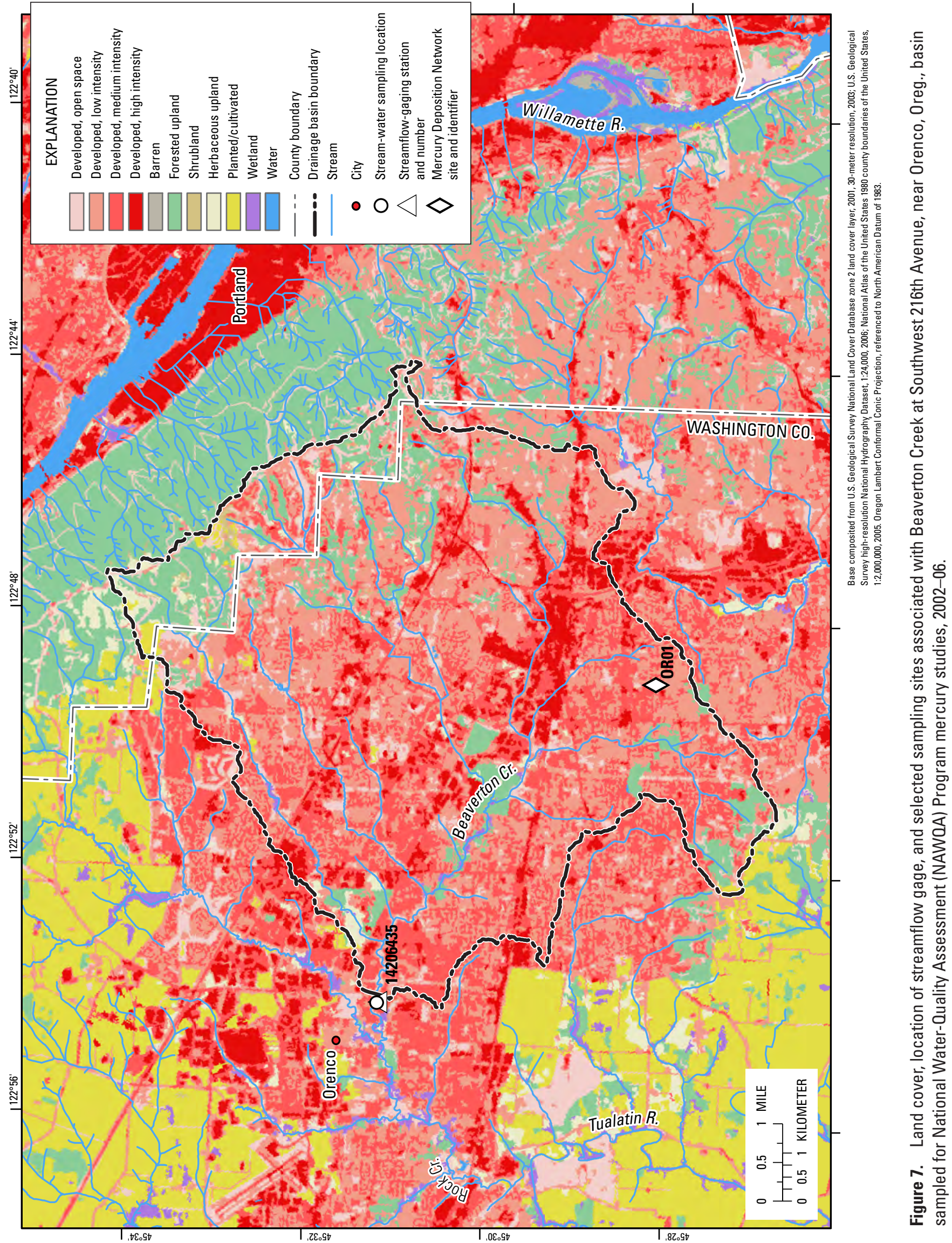



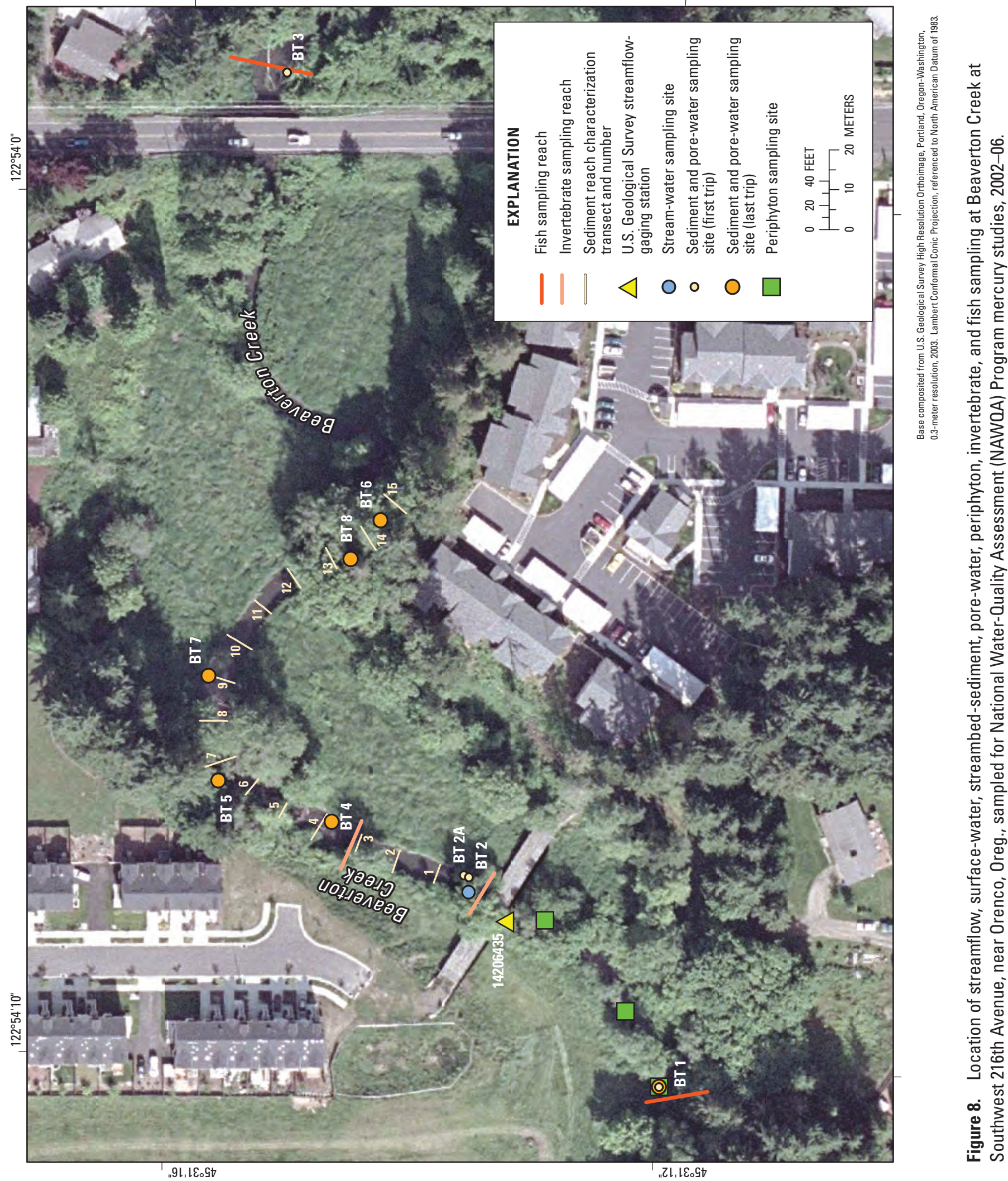


\section{Wisconsin Streams}

The Wisconsin streams sampled for the 2002-06 NAWQA Hg studies are Pike River at Amberg, Wis., Evergreen River below Evergreen Falls near Langlade, Wis., and Oak Creek at South Milwaukee, Wis. (fig. 9, table 1). Pike River is a nonurban, high-percentage (17.9 percent) wetland stream located in northeastern Wisconsin (table 2). Evergreen River is a nonurban, low-percentage (13.4 percent) wetland stream located southwest of the Pike River. Oak Creek is an urban stream located near Milwaukee, Wis. Drainage basins of these streams have moderate percentages of wetland land cover compared to the basins of similarly categorized (for example, urban) streams in other States.

This area of the country has a more extreme climate than the other areas studied. Mean air temperatures near the three Wisconsin sampling sites ranged from about $20^{\circ} \mathrm{C}$ in the summer to about $-6^{\circ} \mathrm{C}$ in the winter (table 3 ); winter air

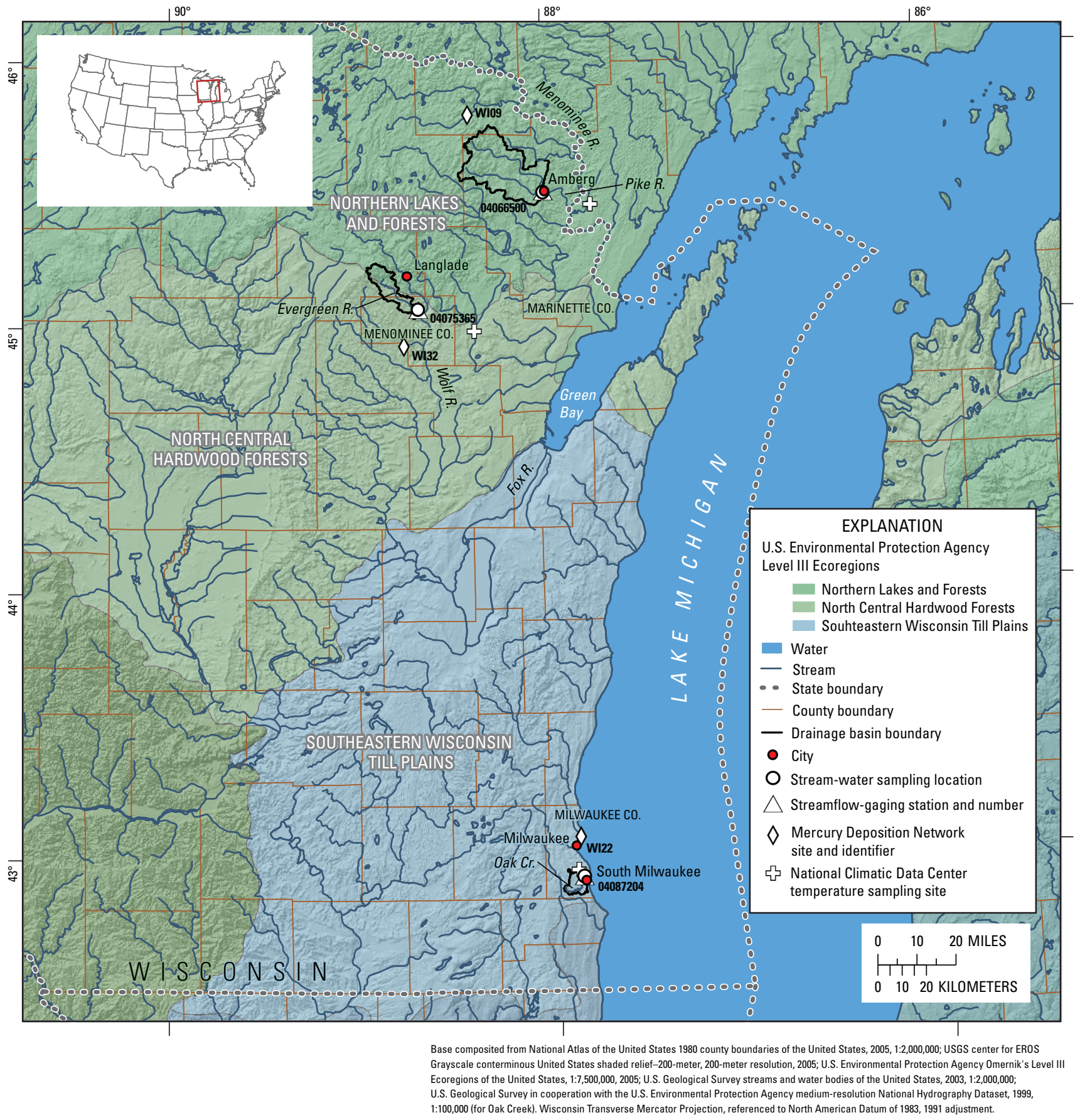

Figure 9. Stream basins, U.S. Environmental Protection Agency Level III Ecoregions, and selected sampling sites associated with Wisconsin streams sampled for National Water-Quality Assessment (NAWQA) Program mercury studies, 2002-06. 
temperatures near these sites were substantially lower than near sites in the other two States. In addition, annual normal (1971 through 2000) precipitation in these drainage basins (about $82 \mathrm{~cm}$ ) was substantially lower than precipitation in basins in the other two States (all greater than $100 \mathrm{~cm}$ ). The following sections describe the environmental settings of the three Wisconsin streams in greater detail.

\section{Pike River}

Pike River is a fourth-order stream, and the sampling site is located in Marinette County at Amberg, Wis. (figs. 9 and $\underline{10}$, table 1). This northern Wisconsin trout stream flows through the 18-km² Pike Wild River State Wildlife Area (fig. 11). Pike River flows into the Menominee River, and then into Lake Michigan via Green Bay (fig. 9).

The Pike River drainage basin covers $660 \mathrm{~km}^{2}$ and is located in the Northern Lakes and Forest Level III USEPA Ecoregion (fig. 9, tables 1 and 2). Land cover in the basin consists primarily (71.0 percent) of upland forests with 17.9 percent wetlands and less than 5 percent developed land (fig. 11, table 2). In-stream sampling locations and reaches are displayed on the digital orthophoto of the stream (fig. 12).

Mean air temperatures from 2002 through 2006 were $18.7^{\circ} \mathrm{C}$ in summer (June through August) and $-6.2^{\circ} \mathrm{C}$ in winter (December through February) (table 3). Annual mean water temperatures ranged from $-0.3^{\circ} \mathrm{C}$ to $24.6^{\circ} \mathrm{C}$ with a mean of $7.0^{\circ} \mathrm{C}$. Annual normal (1971 through 2000) precipitation for the Pike River drainage basin is $78.5 \mathrm{~cm}$; precipitation for the 2002 through 2005 calendar years was generally above normal (1.5-17.4 cm), except for 2005 (4.3 cm below normal). Mean annual streamflow for the period of record (calendar years 2001 through 2005) was $5.66 \mathrm{~m}^{3} / \mathrm{s}$ (table 4); from 2002 through 2005 (calendar years) annual streamflow ranged from $4.78 \mathrm{~m}^{3} / \mathrm{s}$ (2005) to $6.88 \mathrm{~m}^{3} / \mathrm{s}$ (2002). The average stream width measured in the bed-sediment and pore-water sampling reach during low-flow conditions was $25.7 \mathrm{~m}$; the streambed substrate was composed primarily of gravel, cobble, and sand.

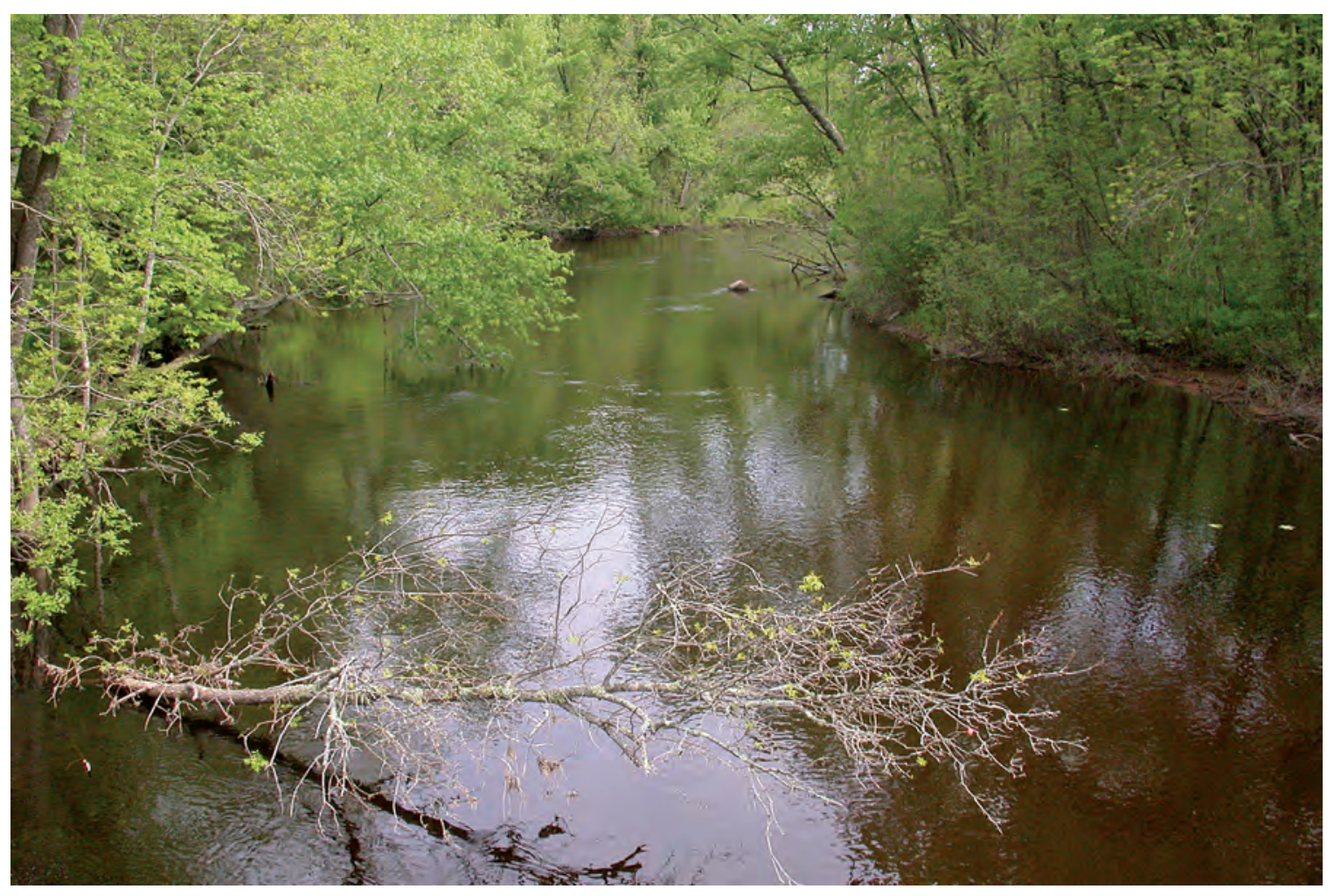

Figure 10. Pike River at Amberg, Wis., (looking upstream) sampled for National Water-Quality Assessment (NAWQA) Program mercury studies, 2002-06. (Photograph by Dennis A. Wentz, U.S. Geological Survey, June 2003.) 


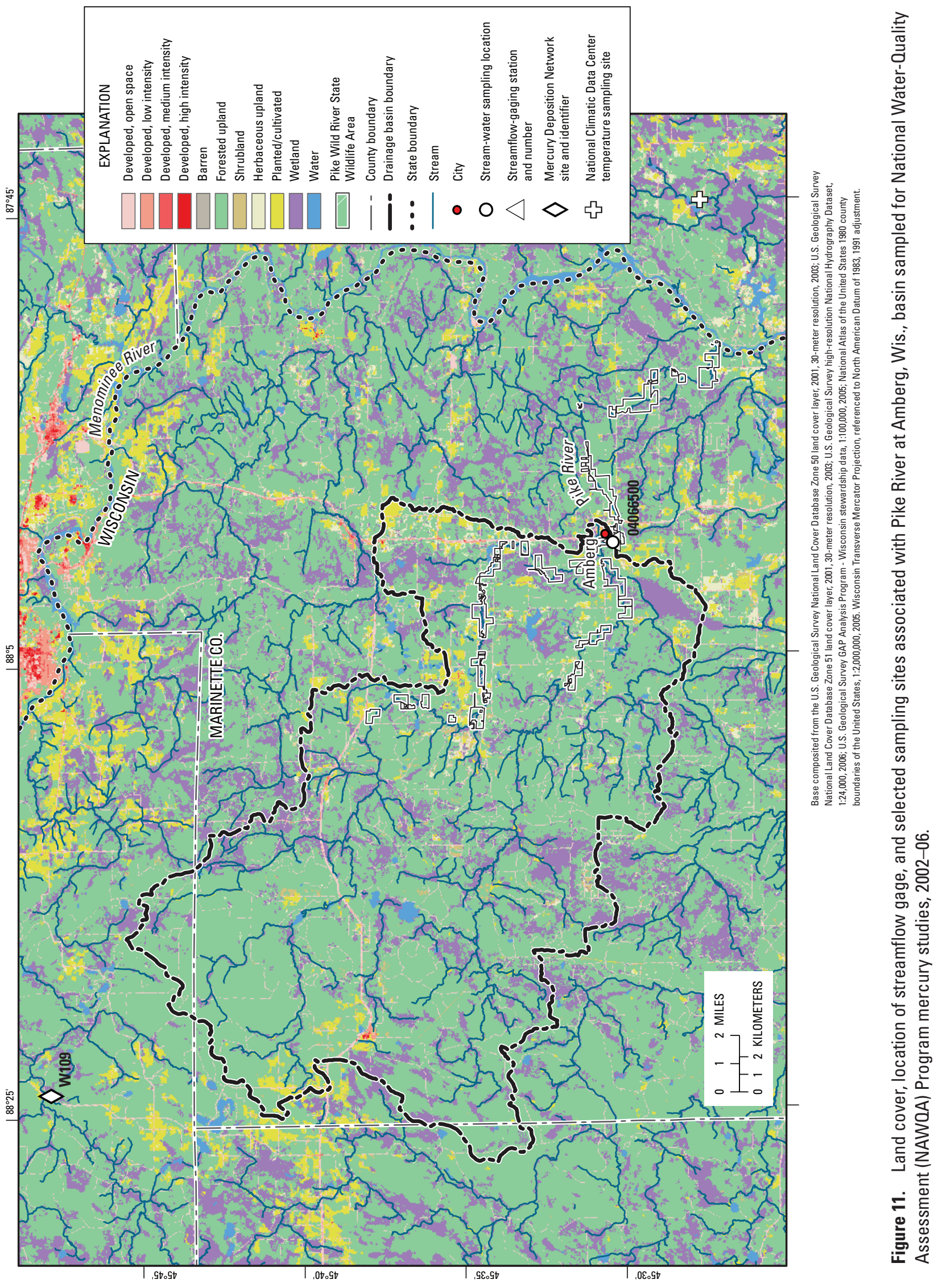




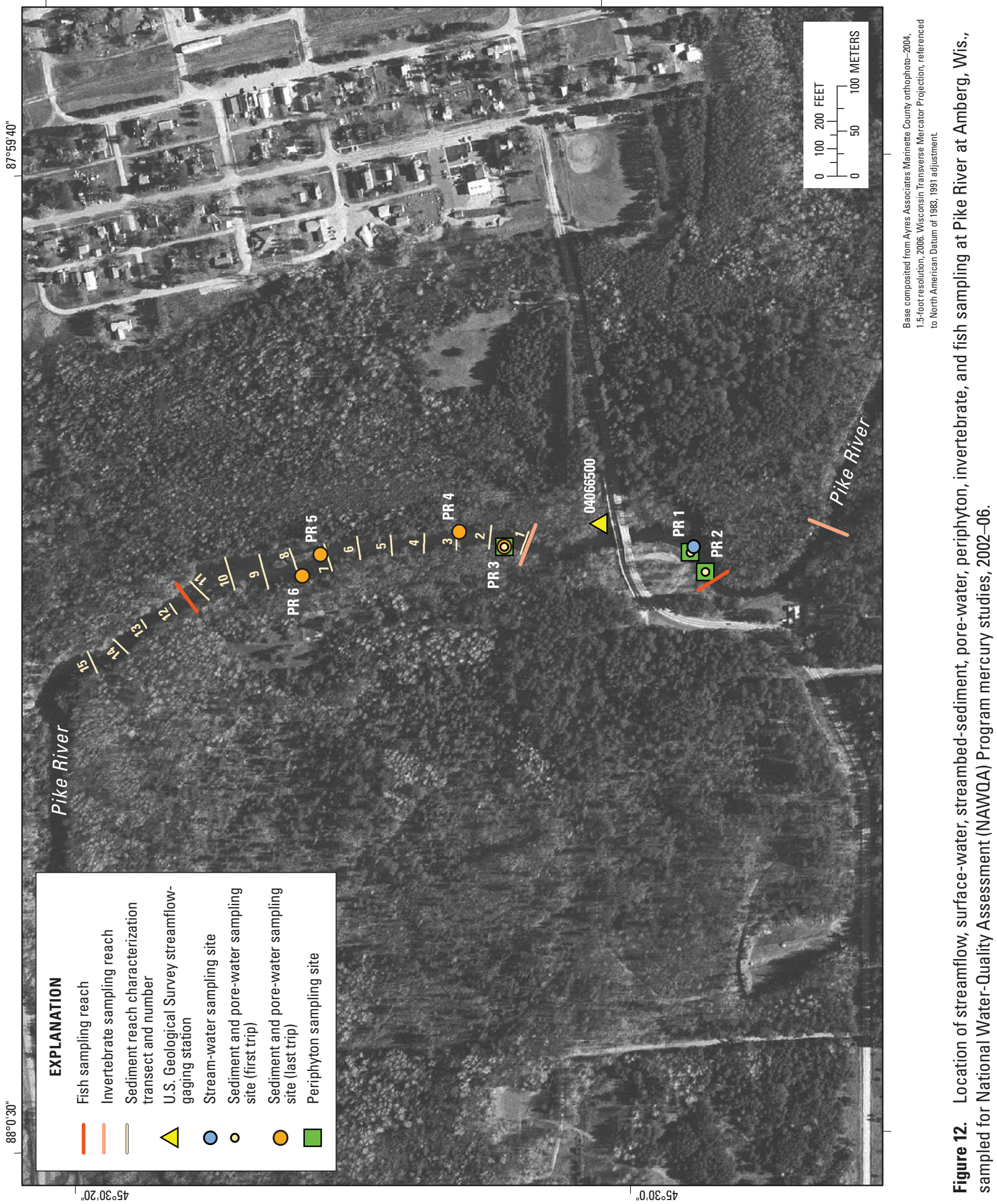




\section{Evergreen River}

Evergreen River is a third-order stream, and the sampling site is located in Menominee County, near Langlade, Wis. (figs. 9 and $\underline{13}$, table 1). It contains many springs and is considered an excellent trout fishery. The stream flows through the Evergreen River State Fishery Area into the Menominee Indian Reservation, where all samples were collected (fig. 14). Evergreen River flows into the Wolf River, then into the Fox River, and finally into Lake Michigan via Green Bay (fig. 9).

The Evergreen River drainage basin covers $167 \mathrm{~km}^{2}$ (table 1). It is located mostly in the North Central Hardwood Forests Level III USEPA Ecoregion, with part falling in the Northern Lakes and Forests Ecoregion (fig. 9, table 2). Land cover in the basin consists primarily (72.1 percent) of upland forests with 13.4 percent wetlands and less than 5 percent developed land (fig. 14, table 2). In-stream sampling locations and reaches are displayed on the digital orthophoto of the stream (fig. 15).

Mean air temperatures from 2002 through 2006 were $19.7^{\circ} \mathrm{C}$ in summer (June through August) and $-7.2^{\circ} \mathrm{C}$ in winter (December through February) (table 3). Annual mean water temperatures ranged from $-0.3^{\circ} \mathrm{C}$ to $24.4^{\circ} \mathrm{C}$ with a mean of $6.9^{\circ} \mathrm{C}$. Annual normal (1971 through 2000) precipitation for the Evergreen River drainage basin is $81.4 \mathrm{~cm}$; precipitation for the 2002 through 2005 calendar years ranged from $7.3 \mathrm{~cm}$ below (2005) to $14.2 \mathrm{~cm}$ above (2002) normal. Mean annual streamflow for the period of record (calendar years 2003 through 2005) was $1.79 \mathrm{~m}^{3} / \mathrm{s}$ (table 4); during this time annual streamflow ranged from $1.65 \mathrm{~m}^{3} / \mathrm{s}$ (2005) to $1.92 \mathrm{~m}^{3} / \mathrm{s}$ (2004). The average stream width measured in the bed-sediment and pore-water sampling reach during low-flow conditions was $14.7 \mathrm{~m}$; the streambed substrate was composed primarily of gravel and sand with areas of high-organic, fine sediment.

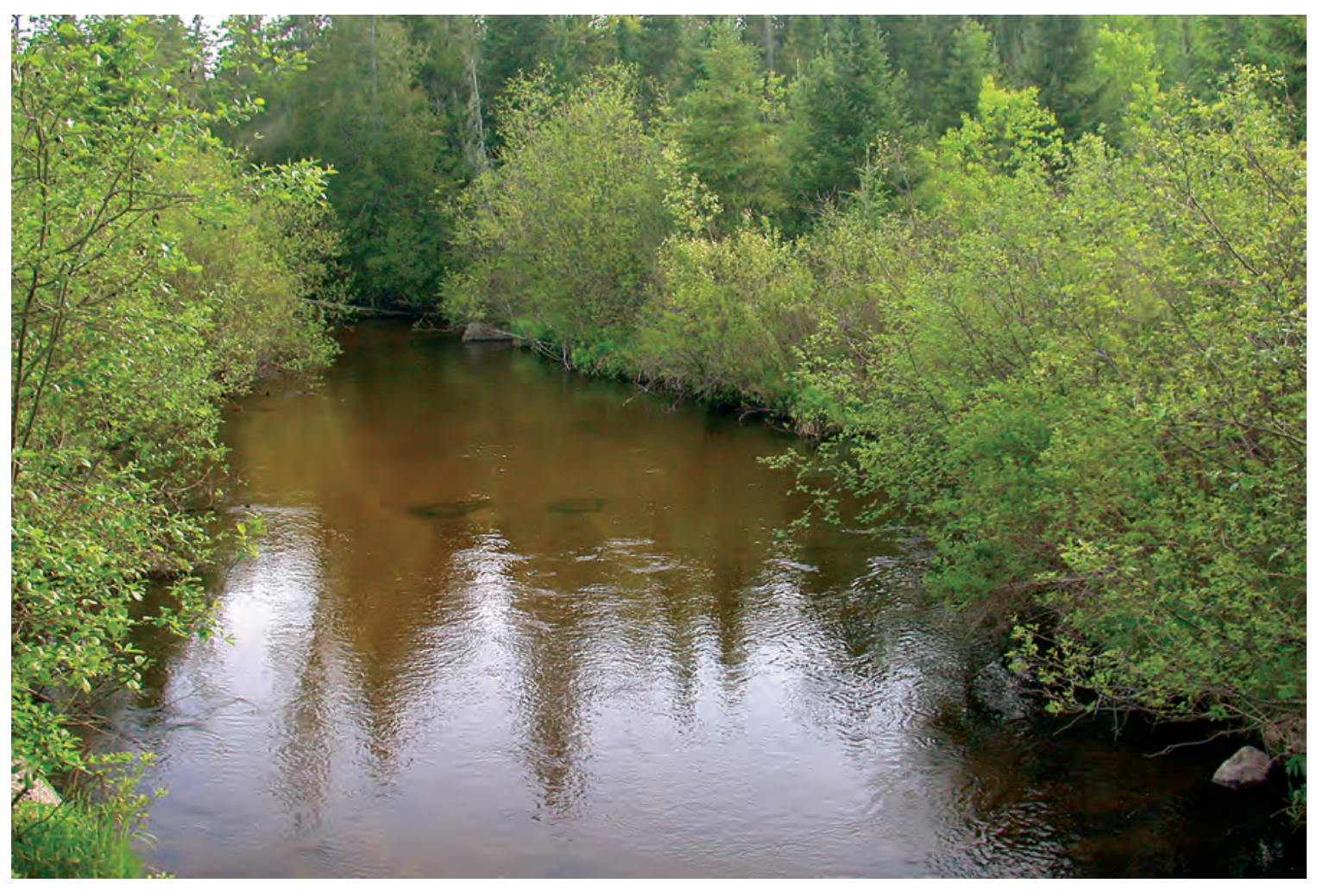

Figure 13. Evergreen River below Evergreen Falls near Langlade, Wis., (looking upstream) sampled for National Water-Quality Assessment (NAWQA) Program mercury studies, 2002-06. (Photograph by Dennis A. Wentz, U.S. Geological Survey, June 2003.) 

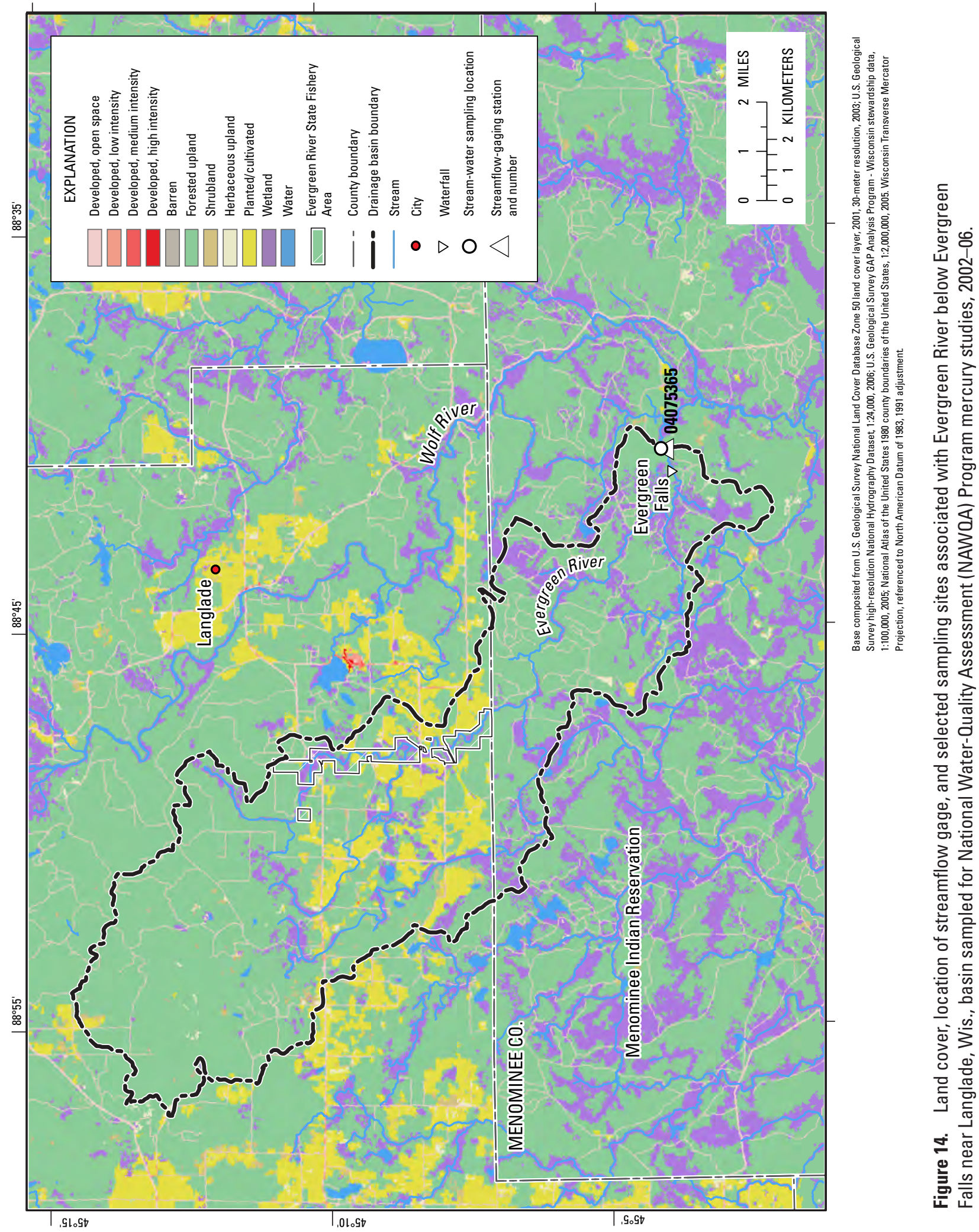


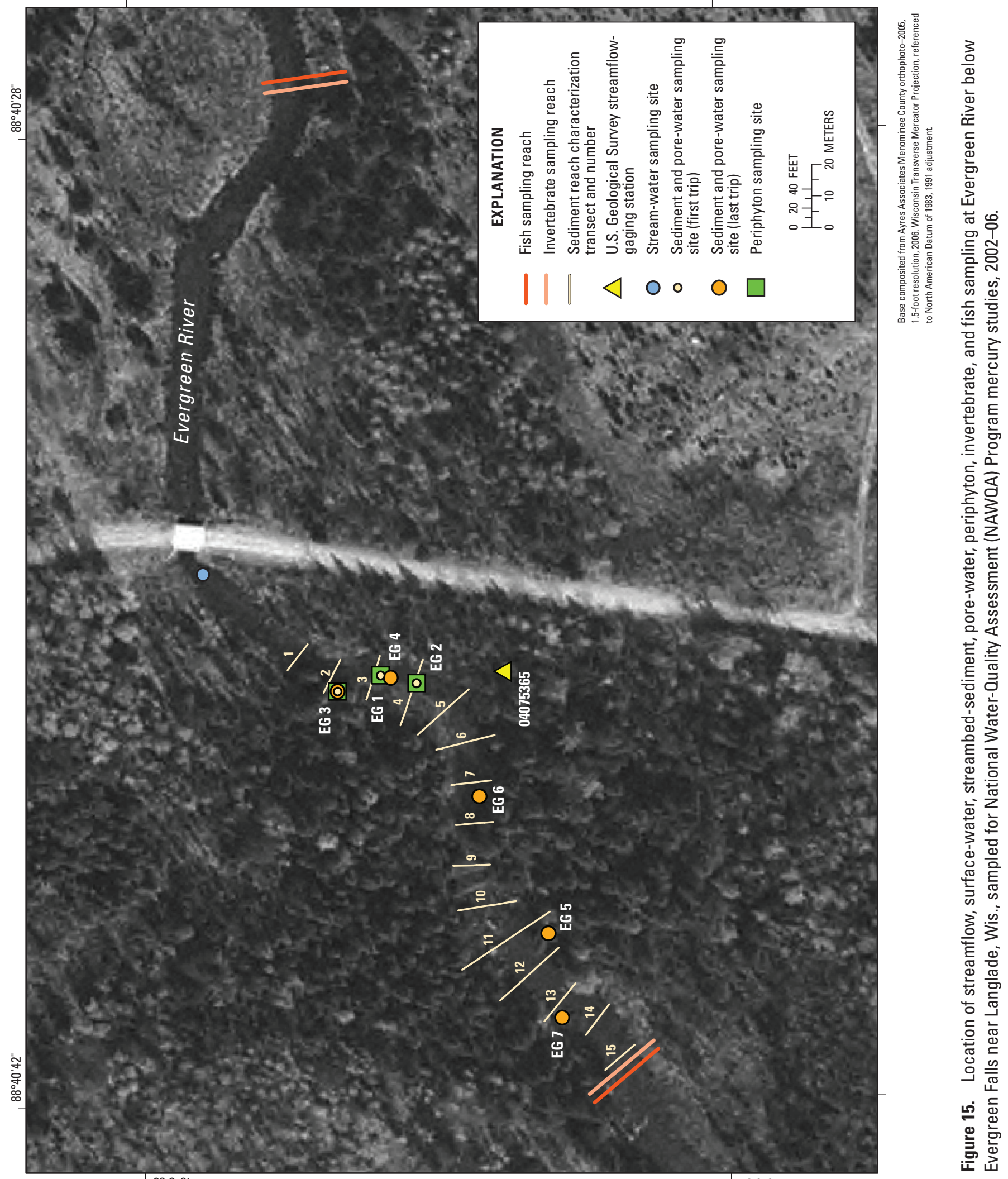




\section{Oak Creek}

Oak Creek is a fourth-order stream, and the sampling site is located in Milwaukee County at South Milwaukee, Wis. (igs. 9 and $\underline{16}$, table 1). It is an urban stream located in the Milwaukee metropolitan area (fig. 17). The Oak Creek Parkway, an urban green space composed of mixed deciduous trees, bushes, and perennial and mowed grasses, lines about $14 \mathrm{~km}$ of the stream's riparian area, and the upper headwaters flow through General Mitchell International Airport. Oak Creek flows directly into Lake Michigan (ig. 9).

The Oak Creek drainage basin covers $64.7 \mathrm{~km}^{2}$ and is located in the Southeastern Wisconsin Till Plains Level III USEPA Ecoregion (fig. 9, tables 1 and 2). Land cover in the basin consists primarily (58.9 percent) of developed land (24.8 percent impervious surface) with less than 4 percent wetlands (fig. 17, table 2). In-stream sampling locations and reaches are displayed on the digital orthophoto of the stream (fig. 18).
Mean air temperatures from 2002 through 2006 were $21.1^{\circ} \mathrm{C}$ in summer (June through August) and $-3.3^{\circ} \mathrm{C}$ in winter (December through February) (table 3). Annual mean water temperatures ranged from $-0.4^{\circ} \mathrm{C}$ to $25.0^{\circ} \mathrm{C}$ with a mean of $8.8^{\circ} \mathrm{C}$. Annual normal (1971 through 2000) precipitation for the Oak Creek drainage basin is $87.4 \mathrm{~cm}$; precipitation for the 2002 through 2005 calendar years ranged from $24.5 \mathrm{~cm}$ below (2003) to $5.9 \mathrm{~cm}$ above (2005) normal. Mean annual streamflow for the period of record (calendar years 1992 through 2005) was $0.66 \mathrm{~m}^{3} / \mathrm{s}$ (table 4); from 2002 through 2005 (calendar years) annual streamflow ranged from $0.28 \mathrm{~m}^{3} / \mathrm{s}$ (2003) to $0.68 \mathrm{~m}^{3} / \mathrm{s}$ (2004). The average stream width measured in the bed-sediment and pore-water sampling reach during low-flow conditions was $7.32 \mathrm{~m}$; the streambed substrate was primarily composed of gravel and cobble with areas of sand.

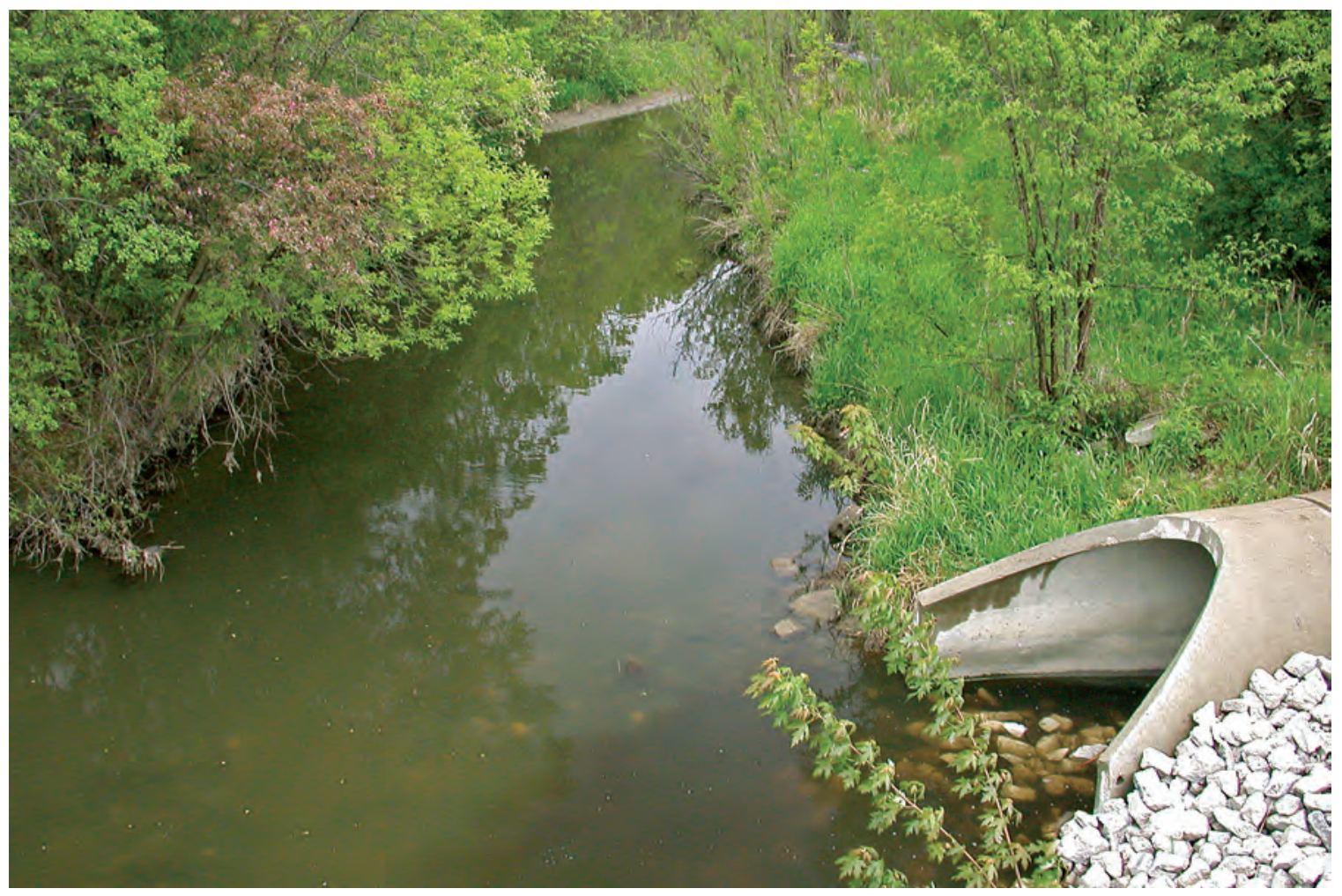

Figure 16. Oak Creek at South Milwaukee, Wis., (looking upstream) sampled for National Water-Quality Assessment (NAWQA) Program mercury studies, 2002-06. (Photograph by Dennis A. Wentz, U.S. Geological Survey, June 2003.) 


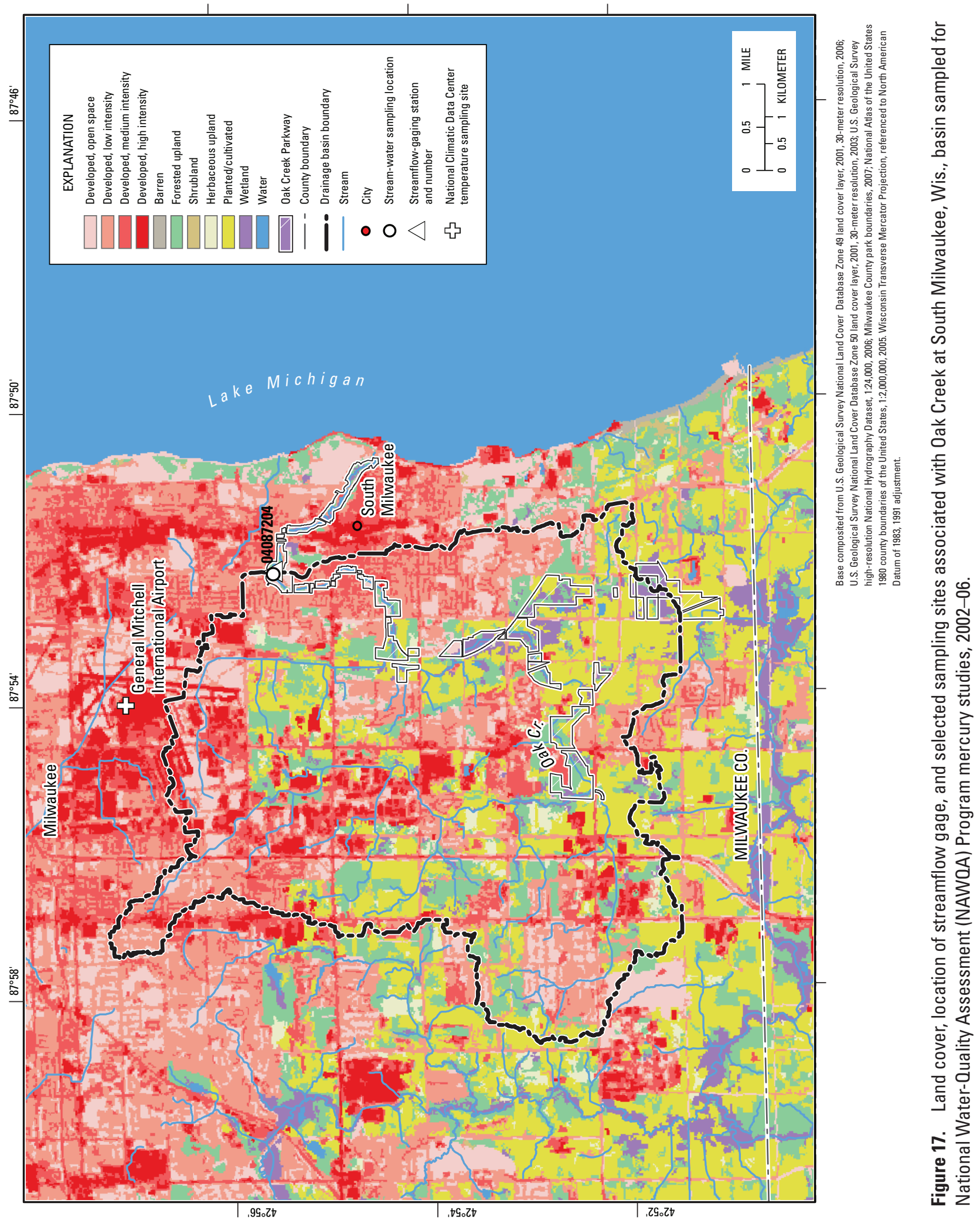




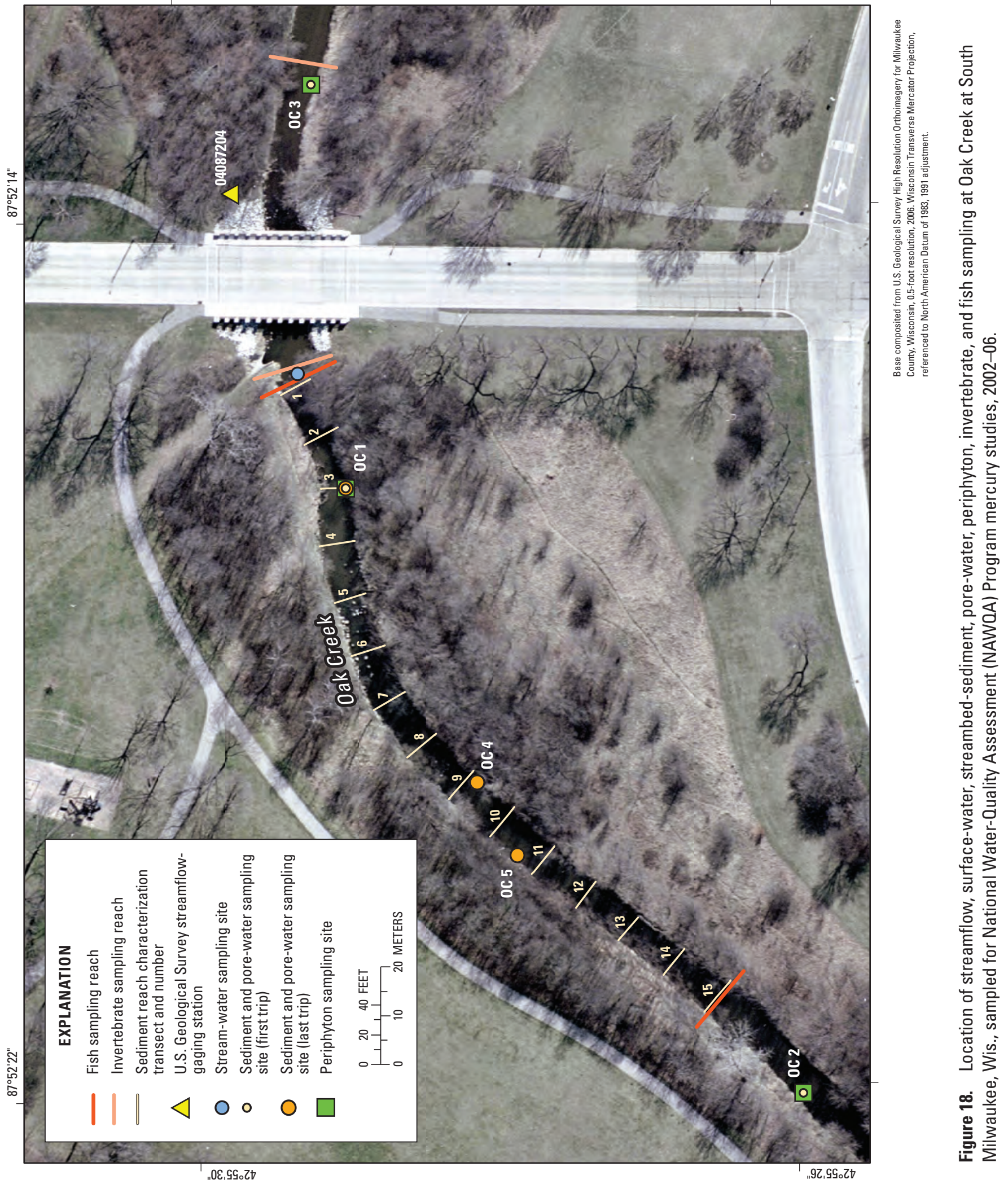




\section{Florida Streams}

The Florida streams sampled for the 2002-06 NAWQA Hg studies are St. Marys River near Macclenny, Fla., Santa Fe River near Fort White, Fla., and Little Wekiva River near Longwood, Fla. (fig. 19, table 1). The St. Marys River is a nonurban, high-percentage (35.6 percent) wetland stream that forms part of the border between Georgia and Florida (table 2). The Santa Fe River is a nonurban, low-percentage (17.9 percent) wetland stream located southwest of the St. Marys River. The Little Wekiva River is an urban stream located near Orlando, Florida. Drainage basins of these streams have the highest percentages of wetland land cover compared to basins of similarly categorized (for example, urban) study streams in Oregon and Wisconsin.

This area of the country has a warmer climate than the other areas studied. Mean air temperatures near the three Florida sampling sites ranged from about $27^{\circ} \mathrm{C}$ in the summer to about $13^{\circ} \mathrm{C}$ in the winter, and annual normal (1971 through 2000) precipitation for drainage basins was about $133 \mathrm{~cm}$ (table 3). The following sections describe the environmental settings of the three Florida streams in greater detail.

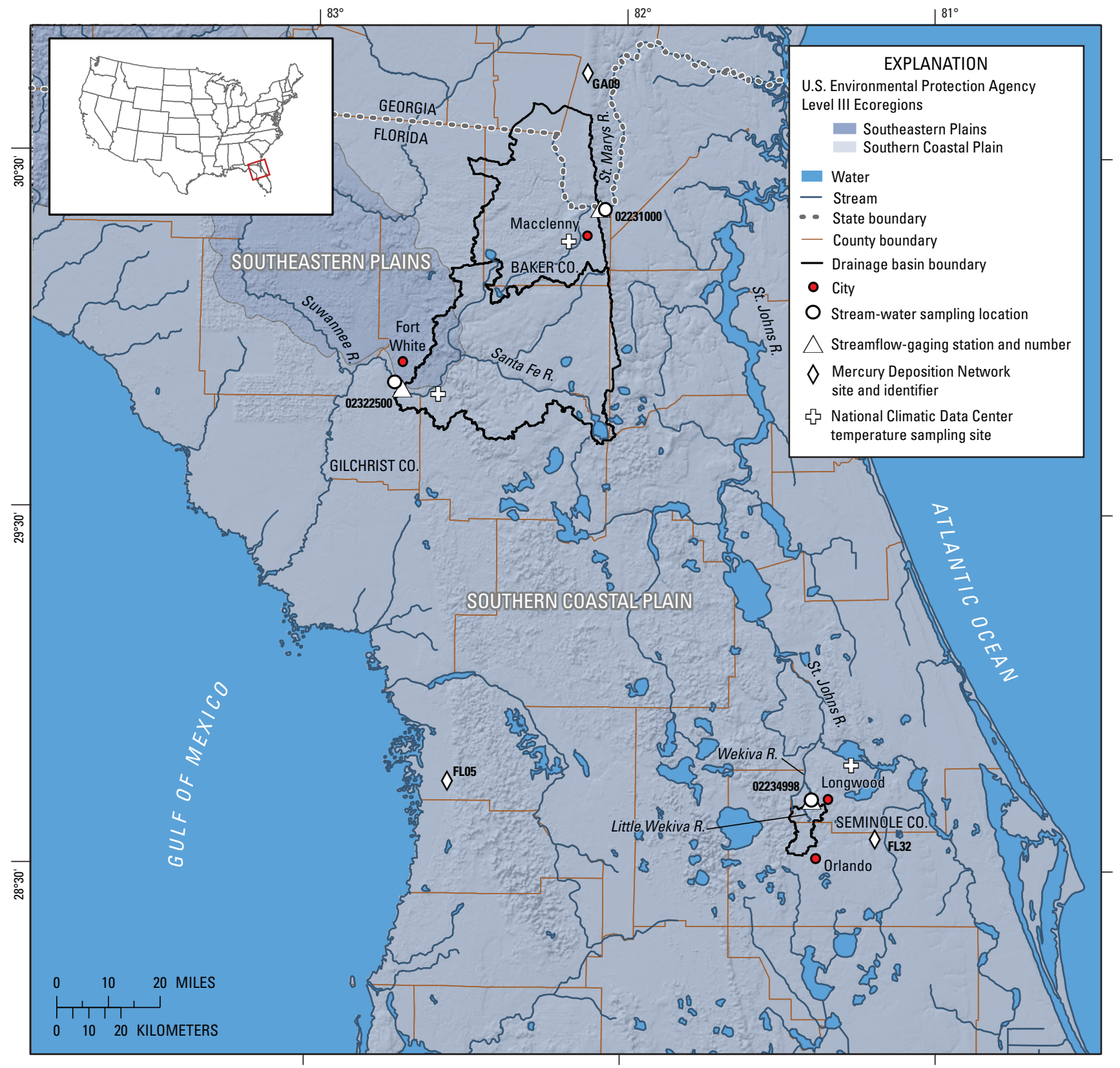

Base composited from National Atlas of the United States 1980 county boundaries of the United States, 2005, 1:2,000,000; USGS center for EROS Grayscale conterminous United States shaded relief-200-meter, 200-meter resolution, 2005; U.S. Environmental Protection Agency Omernik's Level III Ecoregions of the United States, 1:7,500,000, 2005; U.S. Geological Survey streams and water bodies of the United States, 2003, 1:2,000,000; U.S. Geological Survey in cooperation with the U.S. Environmental Protection Agency high-resolution National Hydrography Dataset, 2006, 1:24,000 (for Little Wekiva River). Universal Transverse Mercator (Zone 17) Projection, referenced to North American Datum of 1983.

Figure 19. Stream basins, U.S. Environmental Protection Agency Level III Ecoregions, and selected sampling sites associated with Florida streams sampled for National Water-Quality Assessment (NAWOA) Program mercury studies, 2002-06. 


\section{St. Marys River}

The St. Marys River is a fifth-order stream, and the sampling site is located in Baker County, near Macclenny, Fla. (figs. 19 and 20, table 1). The headwaters begin in the Okefenokee Swamp and Okefenokee National Wildlife Refuge, with some tributaries beginning in Pinhook Swamp in the Osceola National Forest (fig. 21). The St. Marys River constitutes a section of the border between Georgia and Florida and flows directly into the Atlantic Ocean (fig. 19).

The St. Marys River drainage basin covers $1,810 \mathrm{~km}^{2}$ and is located in the Southern Coastal Plain Level III USEPA Ecoregion (fig. 19, tables 1 and 2). Land cover in the basin consists primarily of upland forests and wetland (41.1 and 35.6 percent, respectively) with less than 6 percent developed land (fig. 21, table 2). The basin contains the highest percentage of wetlands of all eight sites described in this report. In-stream sampling locations and reaches are displayed on the digital orthophoto of the stream (fig. 22).

Mean air temperatures from 2002 through 2006 were $26.8^{\circ} \mathrm{C}$ in summer (June through August) and $11.2^{\circ} \mathrm{C}$ in winter (December through February) (table 3). Annual mean water temperatures ranged from $9.5^{\circ} \mathrm{C}$ to $30.4^{\circ} \mathrm{C}$ with a mean of $23.6^{\circ} \mathrm{C}$. Annual normal (1971 through 2000) precipitation for the St. Marys River drainage basin is $134 \mathrm{~cm}$; precipitation for the 2002 through 2005 calendar years was generally above normal (8.7-22.0 cm), except for 2005 (31.6 cm below normal). Mean annual streamflow for the period of record (calendar years 1992 through 2005) was $16.1 \mathrm{~m}^{3} / \mathrm{s}$ (table 4); from 2002 through 2005 (calendar years) annual streamflow ranged from $6.46 \mathrm{~m}^{3} / \mathrm{s}$ (2002) to $28.7 \mathrm{~m}^{3} / \mathrm{s}$ (2004). The average stream width measured in the bed-sediment and pore-water sampling reach during low-flow conditions was $47.1 \mathrm{~m}$; the streambed substrate was primarily composed of sand.

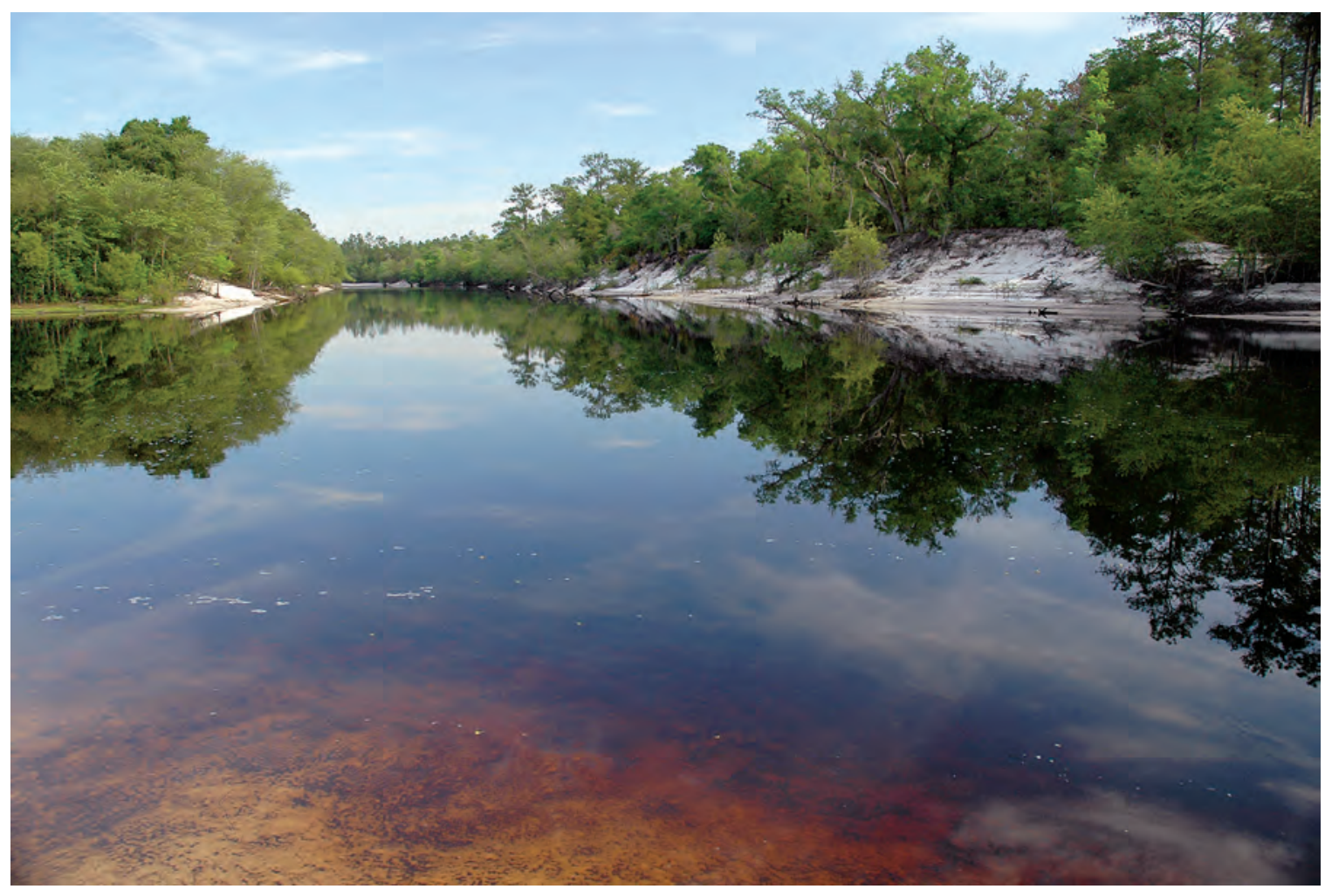

Figure 20. St. Marys River near Macclenny, Fla., (looking upstream) sampled for National Water-Quality Assessment (NAWQA) Program mercury studies, 2002-06. (Photograph by Dennis A. Wentz, U.S. Geological Survey, May 2004.) 

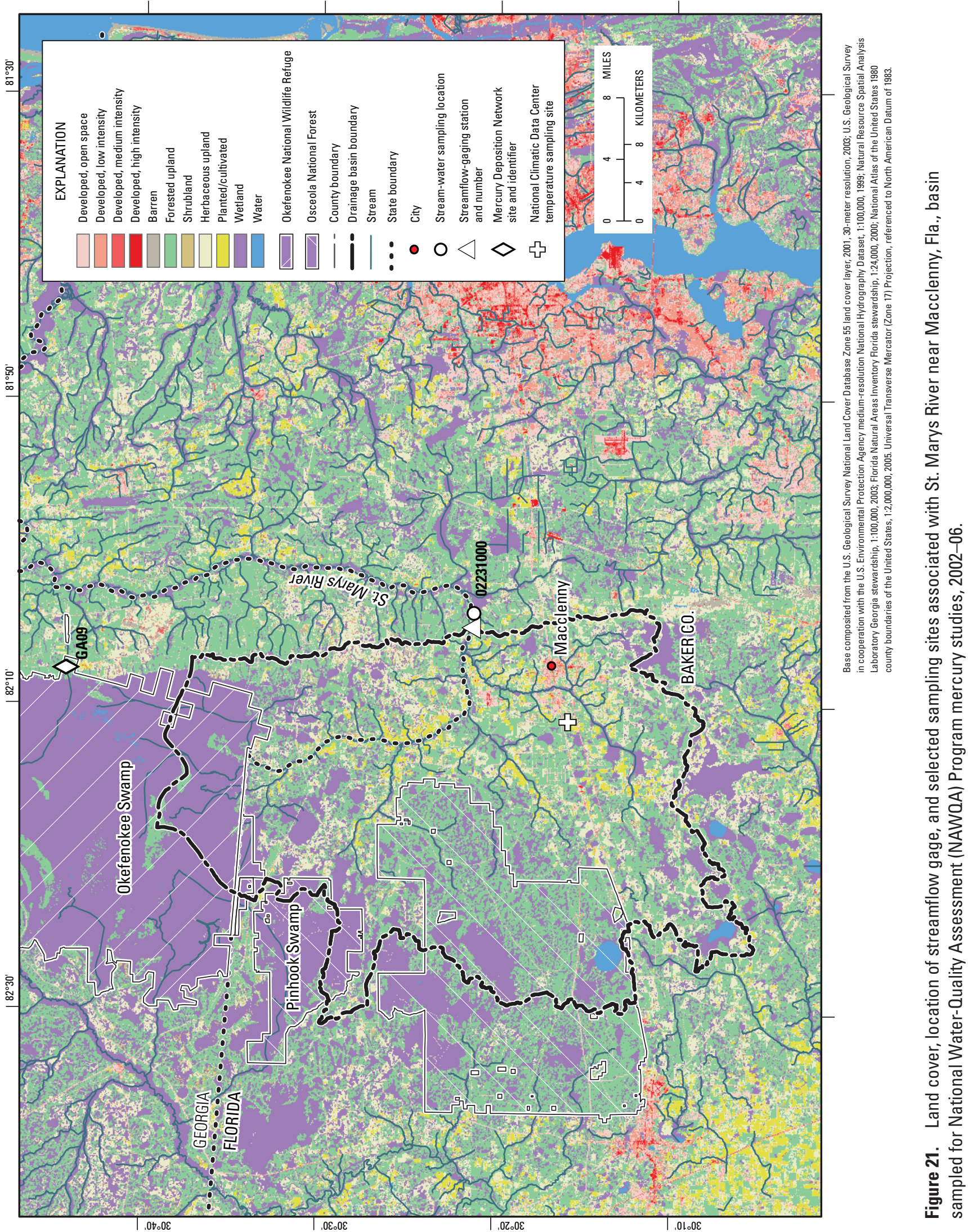


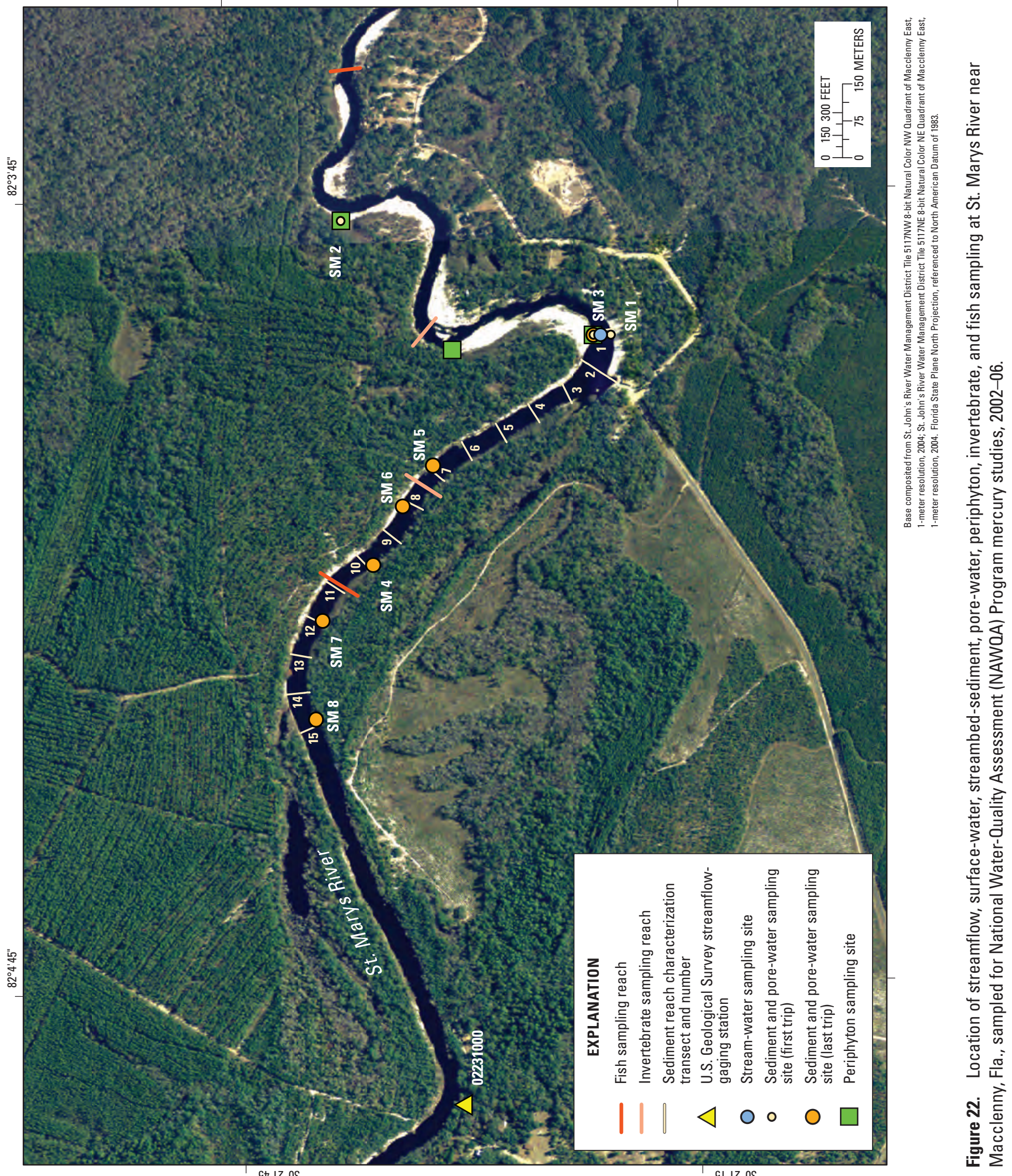




\section{Santa Fe River}

The Santa Fe River is a fourth-order stream, and the sampling site is located in Gilchrist County, near Fort White, Florida (igs. 19 and $\underline{23}$, table 1). The headwaters of the Santa Fe River are in the blackwater Santa Fe and Little Santa Fe Lakes, and Santa Fe Swamp (fig. 24). The Santa Fe River disappears underground in O’Leno State Park, flows underground for $4.8 \mathrm{~km}$, and resurfaces in River Rise Preserve State Park. Throughout the length of the Santa Fe River system, many first-magnitude springs ${ }^{1}$ contribute to this blackwater stream. Santa Fe River is a major tributary to the Suwannee River, which flows into the Gulf of Mexico (fig. 19).

The Santa Fe River drainage basin covers 2,630 $\mathrm{km}^{2}$ and is the largest basin of all eight sites described in this report (table 1). It is located primarily in the Southern Coastal Plain Level III USEPA Ecoregion, with a small part falling in the Southeastern Plains Ecoregion (fig. 19, table 2). Land cover in the basin consists primarily of upland forests and wetlands
(40.6 and 17.9 percent, respectively) with less than 7 percent developed land (fig. 24, table 2). In-stream sampling locations and reaches are displayed on the digital orthophoto of the stream (fig. 25).

Mean air temperatures from 2002 through 2006 were $27.1^{\circ} \mathrm{C}$ in summer (June through August) and $12.3^{\circ} \mathrm{C}$ in winter (December through February) (table 3). Annual mean water temperatures ranged from $17.8^{\circ} \mathrm{C}$ to $25.4^{\circ} \mathrm{C}$ with a mean of $22.4^{\circ} \mathrm{C}$. Annual normal (1971 through 2000) precipitation for the Santa Fe River drainage basin is $135 \mathrm{~cm}$; precipitation for the 2002 through 2005 calendar years was generally above normal (8.6-19.3 cm), except for 2005 (39.1 cm below normal). Mean annual streamflow for the period of record (calendar years 1992 through 2005) was $36.1 \mathrm{~m}^{3} / \mathrm{s}$ (table 4); from 2002 through 2005 (calendar years) annual streamflow ranged from $17.0 \mathrm{~m}^{3} / \mathrm{s}$ (2002) to $47.1 \mathrm{~m}^{3} / \mathrm{s}$ (2004). The average stream width measured in the bed-sediment and pore-water sampling reach during low-flow conditions was $48.8 \mathrm{~m}$; the streambed substrate is composed primarily of limestone bedrock with a thin layer of sand in some areas.

${ }^{1}$ First-magnitude springs are springs with discharges exceeding $2.8 \mathrm{~m}^{3} / \mathrm{s}$.

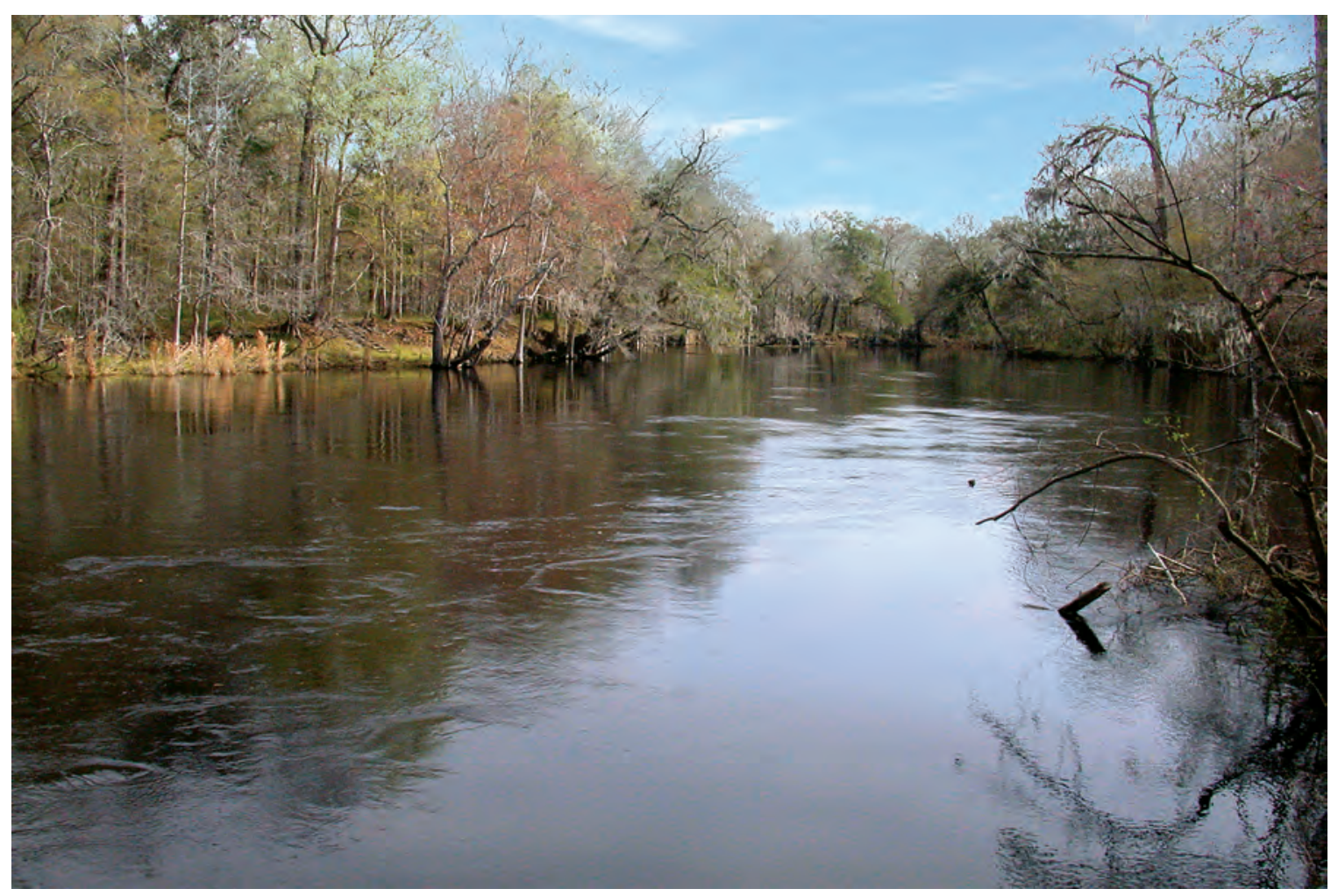

Figure 23. Santa Fe River near Fort White, Fla., (looking downstream) sampled for National Water-Quality Assessment (NAWQA) Program mercury studies, 2002-06. (Photograph by Dennis A. Wentz, U.S. Geological Survey, February 2003.) 


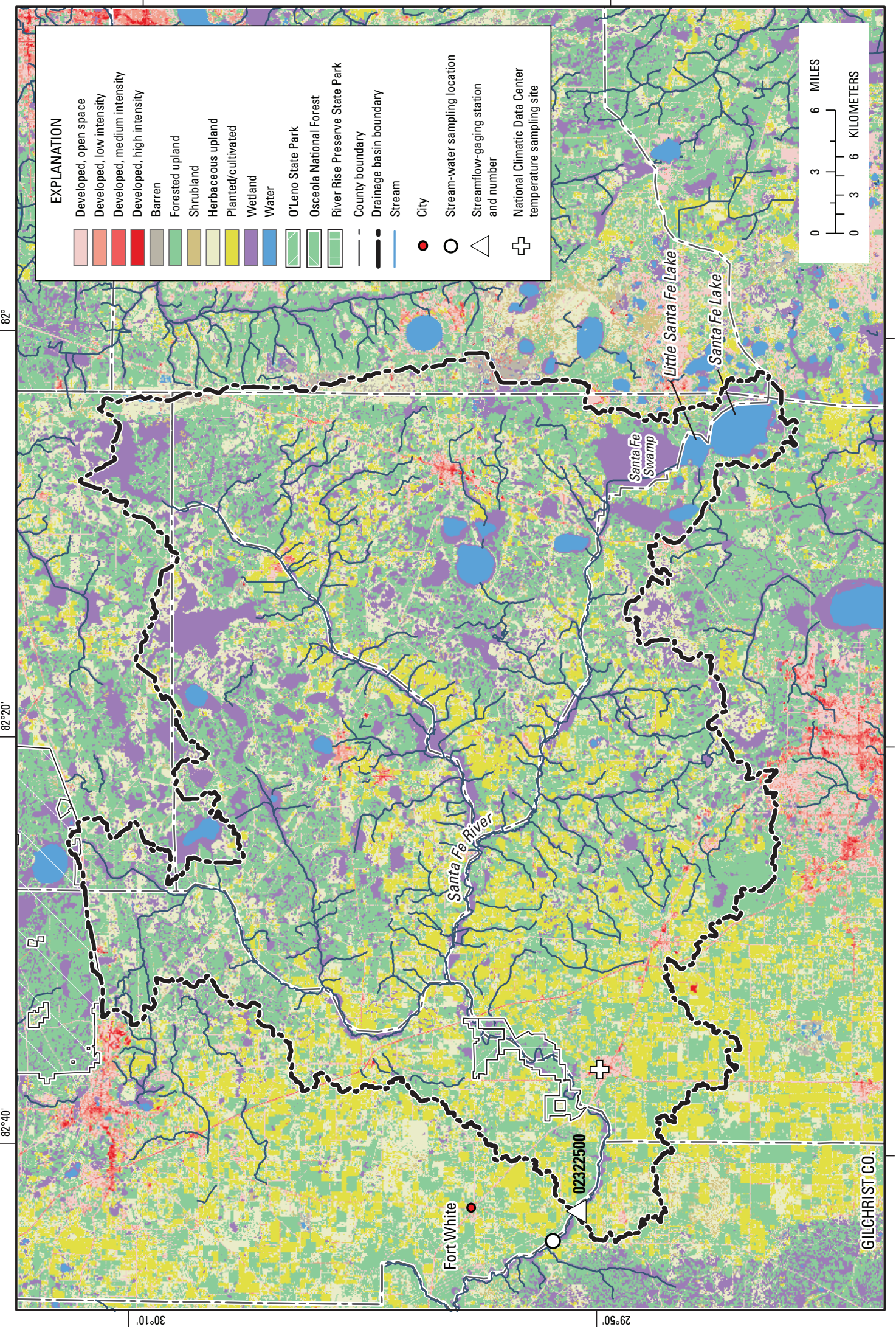




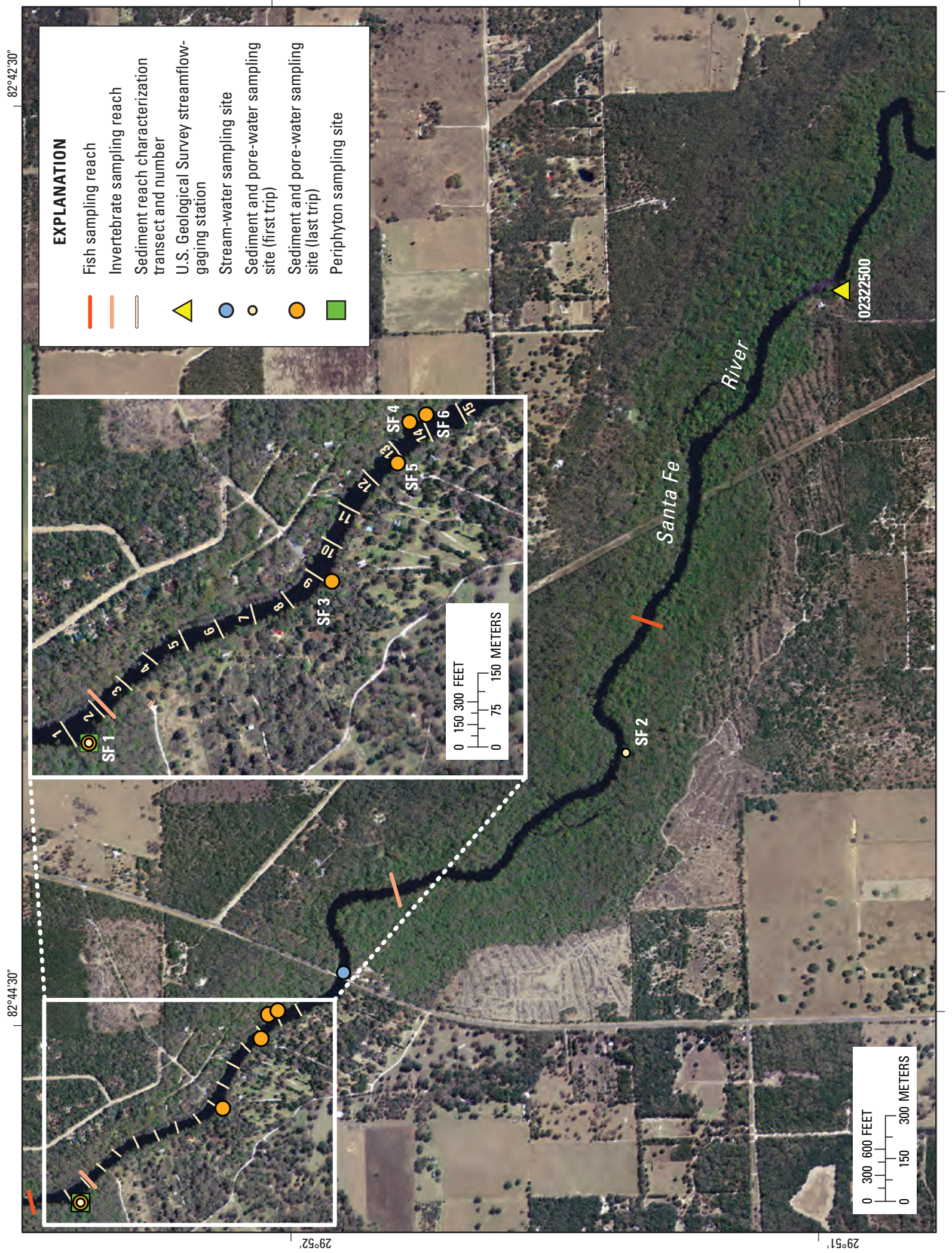

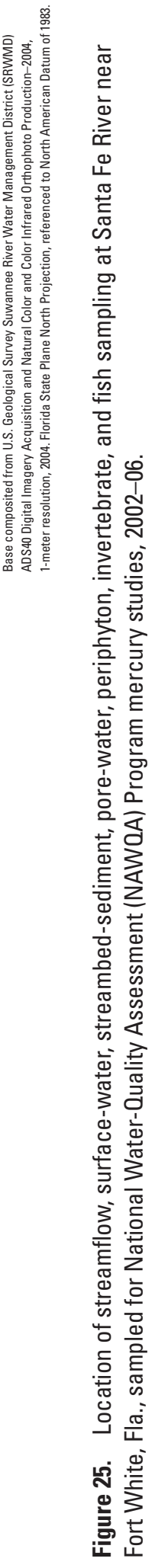




\section{Little Wekiva River}

The Little Wekiva River is a third-order stream, and the sampling site is located in Seminole County, near Longwood, Florida (figs. 19 and 26 , table 1). It is an urban stream located in the Orlando metropolitan area (fig. 27). The headwaters of the Little Wekiva River flow through Spring Lake, and also receive contributions from other smaller lakes and wetlands. The Little Wekiva River flows into the Wekiva River, then into the St. Johns River, and finally into the Atlantic Ocean (fig. 19).

The Little Wekiva River drainage basin covers $115 \mathrm{~km}^{2}$ and is located in the Southern Coastal Plain Level III USEPA Ecoregion (fig. 19, tables 1 and 2). Land cover in the basin consists primarily (77.3 percent) of developed land (25.6 percent impervious surface) with 13.2 percent wetlands (fig. 27, table 2); this is the highest percentage of wetlands among urban streams described in this report. Just upstream from the stream-water sampling site, several springs contribute to streamflow via wetlands along the riparian area. In-stream sampling locations and reaches are displayed on the digital orthophoto of the stream (fig. 28).

Mean air temperatures from 2002 through 2006 were $28.1^{\circ} \mathrm{C}$ in summer (June through August) and $15.7^{\circ} \mathrm{C}$ in winter (December through February) (table 3). Annual mean water temperatures ranged from $20.2^{\circ} \mathrm{C}$ to $28.0^{\circ} \mathrm{C}$ with a mean of $24.1^{\circ} \mathrm{C}$. Annual normal (1971 through 2000) precipitation for the Little Wekiva River drainage basin is $131 \mathrm{~cm}$; precipitation for the 2002 through 2005 calendar years was generally above normal (11.5-39.3 cm), except for 2005 (32.8 cm below normal). Mean annual streamflow for the period of record (calendar years 1996 through 2005) was $2.37 \mathrm{~m}^{3} / \mathrm{s}$ (table 4); from 2002 through 2005 (calendar years) annual streamflow ranged from $2.18 \mathrm{~m}^{3} / \mathrm{s}$ (2002) to $3.04 \mathrm{~m}^{3} / \mathrm{s}$ (2005). The average stream width measured in the bed-sediment and pore-water sampling reach during low-flow conditions was $7.40 \mathrm{~m}$; the streambed substrate is primarily composed of sand with areas of high organic matter.

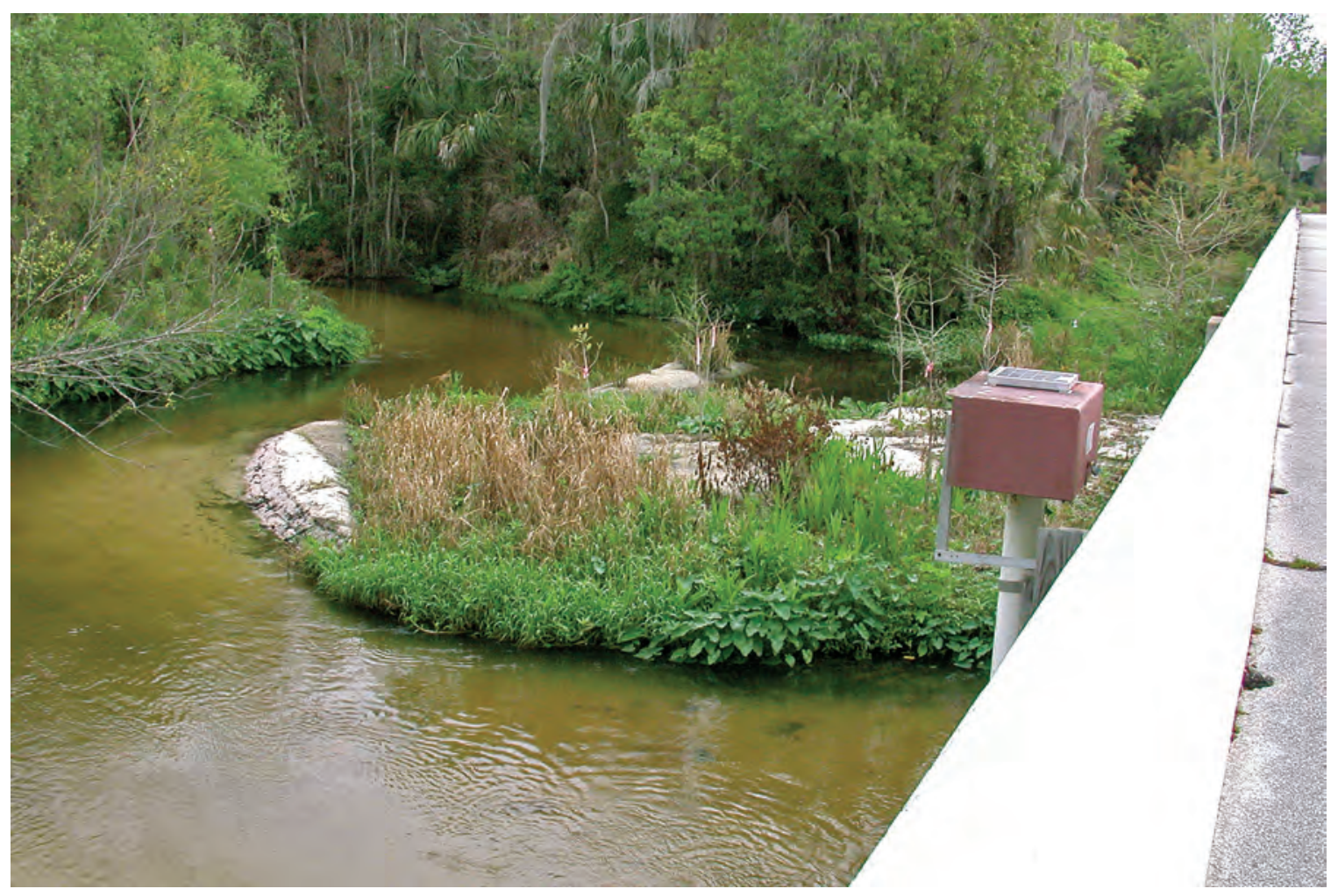

Figure 26. Little Wekiva River near Longwood, Fla., (looking downstream) sampled for National Water-Quality Assessment (NAWQA) Program mercury studies, 2002-06. (Photograph by Dennis A. Wentz, U.S. Geological Survey, February 2003.) 


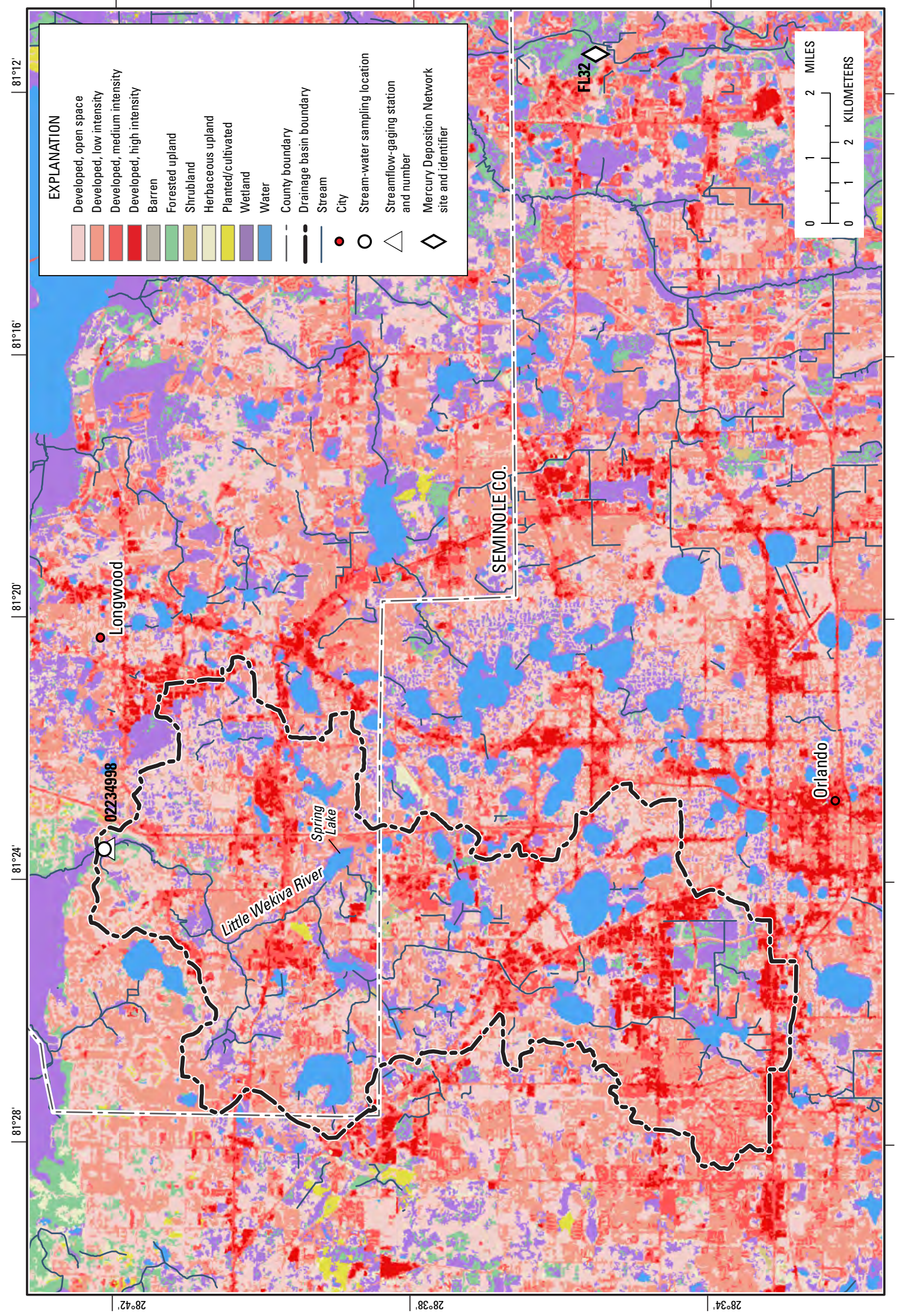




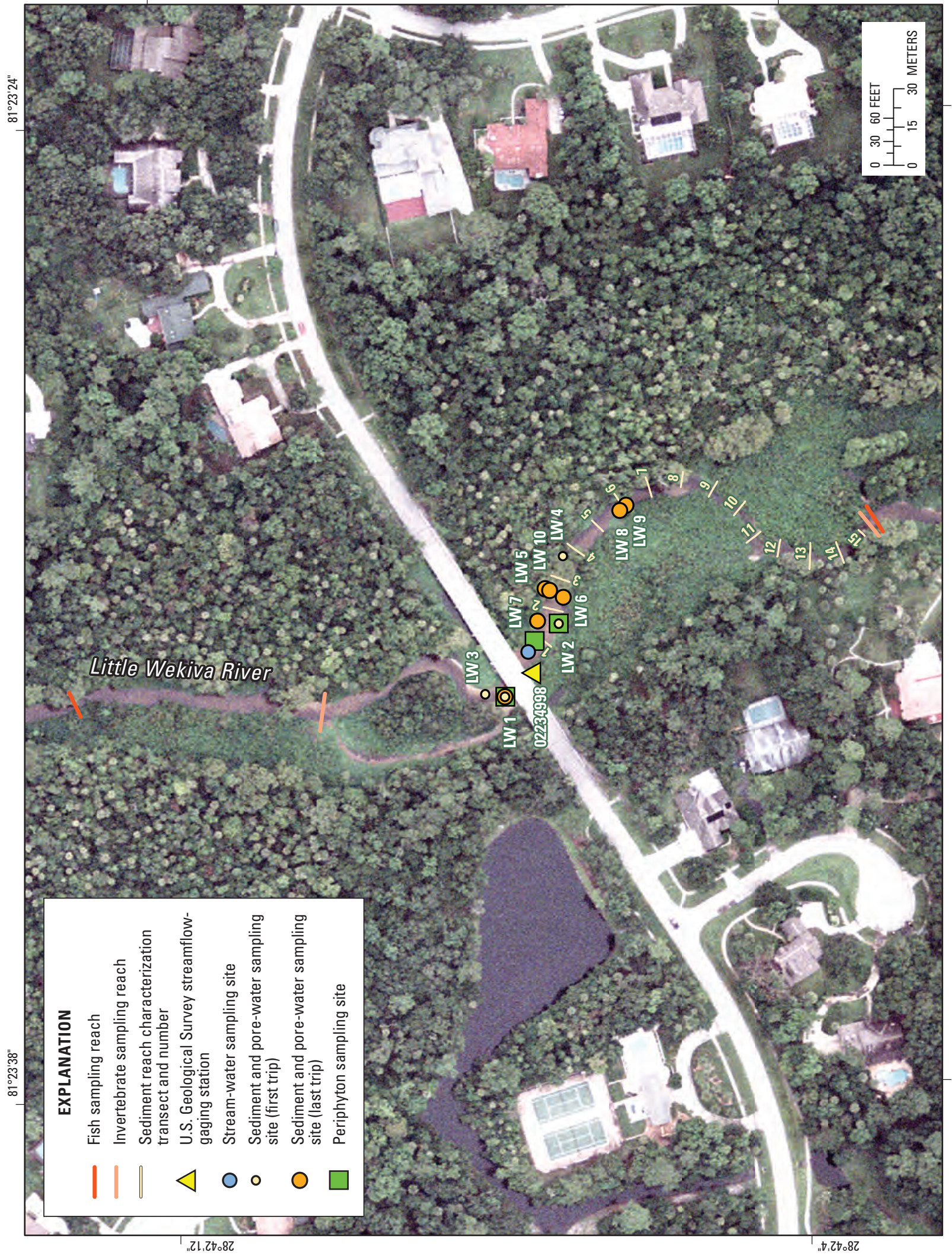




\section{Summary}

Eight streams in Oregon, Wisconsin, and Florida for which detailed studies of Hg were conducted as part of the NAWQA Program represent large gradients in key environmental characteristics that are thought to affect $\mathrm{Hg}$ cycling in stream ecosystems. Additionally, the three areas of the United States in which the streams are located offer distinct climatic characteristics and hydrologic settings. The study sampling sites and sampling reaches allow for comparisons of $\mathrm{Hg}$ in water, bed sediment, pore-water, and aquatic organisms between urban and nonurban streams, and among basins with varying percentages of wetland cover.

\section{Acknowledgments}

The authors thank numerous USGS personnel who contributed information and guidance for this report. We also thank the following agencies for supporting the study and for access to land and data: H.J. Andrews Experimental Forest, Oregon Department of Environmental Quality, and Beaverton School District (Oreg.); Menominee Indian Tribe of Wisconsin, the Wisconsin Department of Natural Resources; and St. Johns River Water Management District, Florida Fish \& Wildlife Conservation Commission, and Florida Department of Environmental Protection.

\section{References Cited}

Brigham, M.E., Krabbenhoft, D.P., and Hamilton, P.A., 2003, Mercury in stream ecosystems - new studies initiated by the U.S. Geological Survey: U.S. Geological Survey Fact Sheet 016-03, 8 p.

Daly, C., and Neilson, R.P., 1992, A digital topographic approach to modeling the distribution of precipitation in mountainous terrain, in Jones, M.E., and Laenen, A., eds., Interdisciplinary approaches in hydrology and hydrogeology: American Institute of Hydrology, p. 437-454.

Daly, C., Neilson, R.P., and Phillips, D.L., 1994, A statisticaltopographic model for mapping climatological precipitation over mountainous terrain: Journal of Applied Meteorology, v. 33, p. $140-158$.

Daly, C., Taylor, G.H., and Gibson, W.P., 1997, The PRISM approach to mapping precipitation and temperature, in Conference on Applied Climatology, 10th, Reno, Nevada, Oct. 20-23, 1997, Proceedings: American Meteorological Society, p. 10-12.
Homer, C., Huang, C., Yang, L., Wylie, B., and Coan, M., 2004, Development of a 2001 national land-cover database for the United States: Photogrammetric Engineering and Remote Sensing, v. 70, no. 7, p. 829-840.

Horton, R.E., 1947, Erosional development of streams and their drainage basins-Hydrophysical approach to quantitative morphology: Geological Society of America, v. 56, p. 275-370.

National Climatic Data Center, 2007, Local climatological data publication: National Oceanic and Atmospheric Administration, National Environmental Satellite, Data, and Information Service, accessed July 1, 2008, at http://www7. ncdc.noaa.gov/IPS/lcd/lcd.html;jsessionid=67B35BF117D2 $\underline{\text { E05322C53B171D0788C3 }}$

Natural Resources Conservation Service, 1998, PRISM spatial climate layers - Climate mapping with PRISM-An overview of the USDA-NRCS Spatial Climate Mapping Project, including an introduction to the PRISM (ParameterElevation Regressions on Independent Slopes Model) system developed by Oregon State University and used to produce spatial climate products: 49 p., accessed July 1, 2008, at http://www.prism.oregonstate.edu/

Oregon Watershed Enhancement Board, 2005, 2003-2005 Oregon plan biennial report, volume 1: Salem, Oregon, 52 p., accessed July 1, 2008, at http://www.oregon.gov/ OWEB/docs/pubs/BiennialReport1 2003-2005.pdf

Strahler, A.N., 1957, Quantitative analysis of watershed geomorphology: American Geophysical Union Transactions, v. 38, p. 913-920.

U.S. Environmental Protection Agency, 2005, Omernik’s level III ecoregions of the continental United States: National Atlas of the United States, Reston, Va., scale 1:7,500,000, accessed July 1, 2008, at http://nationalatlas.gov/mld/ ecoomrp.html

U.S. Geological Survey, 1999, USGS 30-meter resolution, 1/60-degree National Elevation Dataset (NED) for CONUS, Alaska, Hawaii, Puerto Rico, and the U.S. Virgin Islands: Sioux Falls, South Dakota, EROS Data Center, accessed December 15, 2008, at http://ned.usgs.gov/

Yang, L., Huang, C., Homer C., Wylie, B., and Coan, M., 2002, An approach for mapping large-area impervious surfaces synergistic use of Landsat 7 ETM+ and high spatial resolution imagery: Canadian Journal of Remote Sensing, v. 29, no. 2, p. 230-240. 
Publishing support provided by:

Columbus and Tacoma Publishing Service Centers

For more information concerning this publication, contact: Chief, USGS National Water-Quality Assessment Program MS 413 National Center

Reston, VA 20192

(703) 648-5716

Or visit the National Water-Quality Assessment Program site at: http://water.usgs.gov/nawqa/ 
